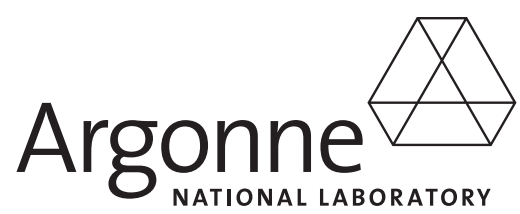

ANL/EVS/AGEM/TR-08-06

\title{
Interim Measure Work Plan/Design for Agra, Kansas
}

\section{Environmental Science Division}


About Argonne National Laboratory

Argonne is a U.S. Department of Energy laboratory managed by UChicago Argonne, LLC under contract DE-AC02-06CH11357. The Laboratory's main facility is outside Chicago, at 9700 South Cass Avenue, Argonne, Illinois 60439. For information about Argonne, see www.anl.gov.

\section{Availability of This Report}

This report is available, at no cost, at http://www.osti.gov/bridge. It is also available on paper to the U.S. Department of Energy and its contractors, for a processing fee, from:

U.S. Department of Energy

Office of Scientific and Technical Information

P.O. Box 62

Oak Ridge, TN 37831-0062

phone (865) 576-8401

fax (865) 576-5728

reports@adonis.osti.gov

\section{Disclaimer}

This report was prepared as an account of work sponsored by an agency of the United States Government. Reference herein to any specific commercial product, process, or service by trade name, trademark, manufacturer, or otherwise, does not necessarily constitute or imply its endorsement, recommendation, or favoring by the United States Government or any agency thereof. The views and opinions of document authors expressed herein do not necessarily state or reflect those of the United States Government or any agency thereof, Argonne National Laboratory, or UChicago Argonne, LLC. 


\section{Interim Measure Work Plan/Design for Agra, Kansas}

by

Applied Geosciences and Environmental Management Section

Environmental Science Division, Argonne National Laboratory

prepared by

GreenField Contractors, Inc.

November 2008

\footnotetext{
USDA 


\section{Contents}

Notation

1 Introduction and Project Objectives ............................................................................... 1-1

2 Construction Specifications.................................................................................... $2-1$

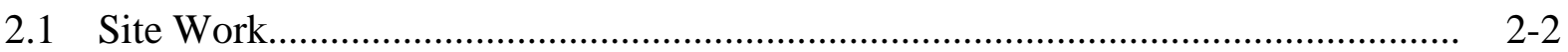

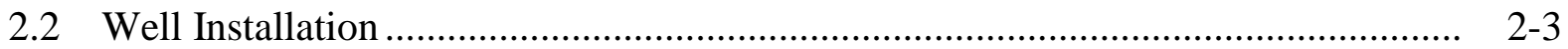

2.2.1 Large-Diameter Borehole SVE/AS Well Installation ............................... 2-3

2.2.2 Monitoring Well Installation............................................................... 2-4

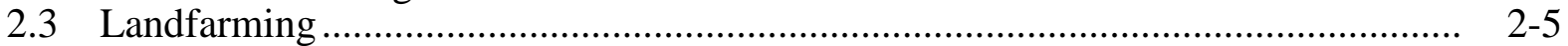

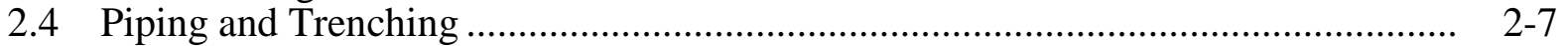

2.4.1 Trenching ................................................................................. $2-8$

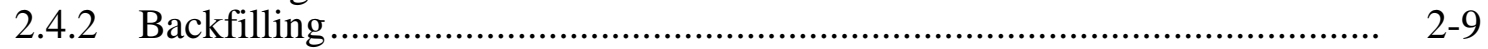

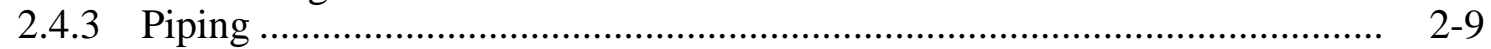

2.5 Electrical Work ……………………………………………………………... 2 2-12

2.6 Equipment Specifications for SVE/AS System .................................................... 2-13

2.6.1 SVE Components ................................................................................ 2-13

2.6.2 AS System ………………………………….................................... 2-15

2.6.3 Equipment Enclosure and Controls ............................................................... 2-16

2.7 Remedial Plans ......................................................................................... 2-17

3 Operation, Maintenance, and Monitoring Specifications.................................................. 3-1

$3.1 \quad$ System Start-up ……................................................................................

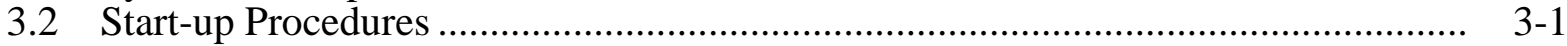

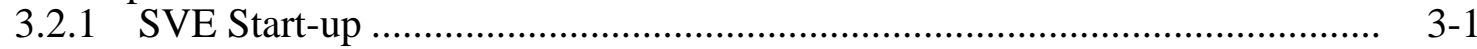

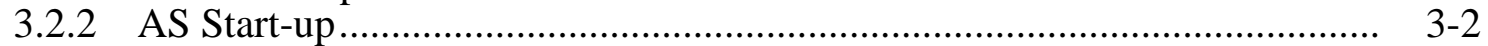

3.3 Operation and Maintenance Requirements ……………......................................... 3-3

3.3.1 Weekly Maintenance …………………………................................... 3-3

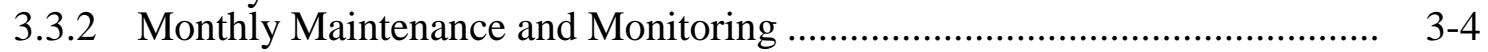

3.3.3 Quarterly Maintenance, Operation, and Monitoring …………………........ 3- 3-5

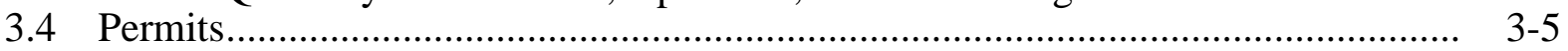

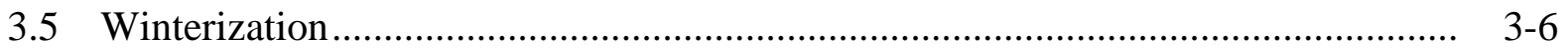

3.6 Property Restoration....................................................................................... 3-6

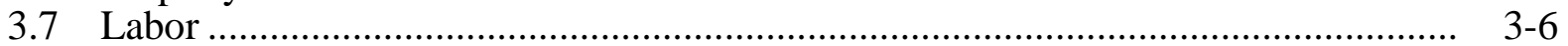

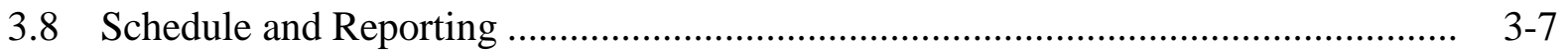

Appendix A: Data Acquisition Plan — Design Testing Requirements ................................. A-1

Appendix B: Basis of Design................................................................................... B-1

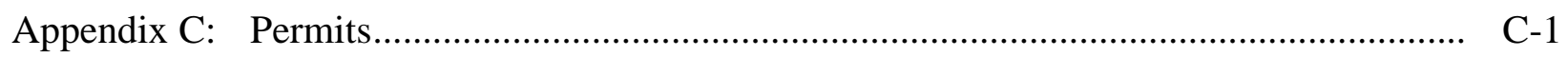

Appendix D: Quality Assurance Project Plan (QAPP) ....................................................... D-1

Appendix E: Health and Safety Plan ........................................................................... E-1

Appendix F: $\quad$ Operations, Maintenance, and Monitoring Schedule _...................................... F- F-1

Drawings 


\section{Notation}

\begin{tabular}{ll} 
AS & air sparging \\
CCC & Commodity Credit Corporation \\
1,2-DCA & 1,2-dichloroethane \\
DO & dissolved oxygen \\
EPA & U.S. Environmental Protection Agency \\
${ }^{\circ} \mathrm{F}$ & degree(s) Fahrenheit \\
$\mathrm{ft}$ & foot (feet) \\
$\mathrm{hr}$ & hour(s) \\
IMWP/D & Interim Measure Work Plan/Design \\
in. & inch(es) \\
KDHE & Kansas Department of Health and Environment \\
LDB & large-diameter borehole \\
$\mu \mathrm{g} / \mathrm{kg}$ & microgram(s) per kilogram \\
mg/kg & milligram(s) per kilogram \\
min & minute(s) \\
NPT & National Pipe Thread \\
NRTL & nationally recognized testing laboratory \\
PID & photoionization detector \\
psi & pounds per square inch \\
PVC & polyvinyl chloride \\
QAPP & Quality Assurance Project Plan \\
scfm & standard cubic feet per minute \\
SVE & soil vapor extraction \\
TCLP & Toxicity Characteristic Leaching Procedure \\
USDA & U.S. Department of Agriculture \\
VOC & volatile organic compound \\
\hline &
\end{tabular}




\section{Interim Measure Work Plan/Design for Agra, Kansas}

\section{Introduction and Project Objectives}

This Interim Measure Work Plan/Design (IMWP/D) is supplemental to the Argonne document Interim Measure Conceptual Design for Remediation of Source Area Contamination at Agra, Kansas. ${ }^{1}$ The IMWP/D includes information required by Kansas Department of Health and Environment (KDHE) Policy BER-RS-029, Policy and Scope of Work for Interim Measures.

Specific to Policy BER-RS-029 is the requirement for several documents that will ensure that an adequate amount and type of data are collected for implementation of the IMWP/D and that data quality and safe conditions are prevailed. Such information is included in the IMWP/D as follows:

- Appendix A: Data Acquisition Plan — Design Testing Requirements

- Appendix B: Basis of Design

- Appendix C: Permits

- Appendix D: Quality Assurance Project Plan

- Appendix E: Health and Safety Plan

- Appendix F: Operations, Maintenance, and Monitoring Schedule

The proposed remedial technology for this project is the installation of five largediameter boreholes (LDBs) in a source area that has been identified on the property formerly used for grain storage by the Commodity Credit Corporation of the U.S. Department of Agriculture (CCC/USDA). The goal of the LDB technology is the remediation of the source area by removal of mass quantities of contaminated soil from the vadose zone and treatment of any remaining contaminated soils that are adjacent to the source area to achieve a carbon

1 Argonne, 2007, Interim Measure Conceptual Design for Remediation of Source Area Contamination at Agra, Kansas, ANL/EVS/AGEM/TR-07-07, prepared for the Commodity Credit Corporation, U.S. Department of Agriculture, Washington, D.C., by Argonne National Laboratory, Argonne, Illinois, July. 
tetrachloride concentration below $200 \mu \mathrm{g} / \mathrm{kg}$. Secondary to the soil remediation is the remediation of groundwater at and adjacent to the source areas.

The LDB technology serves the following purposes:

1. The physical removal of contaminated soil from the identified source area.

2. Replacement of less permeable native materials (silty clay, clayey silt, and silty sand) with more permeable materials to facilitate the capture of volatilized contaminants in the vertical borehole.

3. Removal of contaminants volatilized by air sparging (AS) and extracted from the vadose zone by soil vapor extraction (SVE).

4. Volatilization of contaminants from portions of the affected aquifer that can be accessed from the former CCC/USDA property.

The primary objective of the proposed removal action is removal of mass quantities of carbon tetrachloride from the vadose zone and treatment of any remaining contaminated soils that are adjacent to the source area, to achieve a carbon tetrachloride concentration below $200 \mu \mathrm{g} / \mathrm{kg}$. This objective will be the basis for evaluating system performance. The scope of action outlined in the IMWP/D is limited to the five treatment zones defined by the LDB/SVE/AS locations. Surrounding soils and groundwater will benefit; however, remedial benefits to groundwater will be limited to the area of influence associated with the five treatment zones. While treatment should be aggressive in the vicinity of the LDB locations, the heterogeneity, clay content, and low permeability of the soils will place inherent limits on the area of influence. 


\section{Construction Specifications}

The information presented in this IMWP/D is, in part, derived directly from design parameters and specifications provided by GreenField Contactors, Inc., and MDC Environmental, Inc. These parameters and specifications have been directly incorporated into this IMWP/D where applicable.

The technology proposed for soil-source remediation of carbon tetrachloride at Agra includes the installation of LDBs (6 ft in diameter), coupled with SVE and AS. These technologies have been used successfully at numerous sites in Kansas for remediating both chlorinated solvents and petroleum-related compounds.

The technology includes removing mass quantities of contaminated soil and replacing it with porous medium (sand) through installation of LDBs. In each LDB, an SVE and AS well will be installed in the middle of the borehole. The porous medium in each LDB allows contaminated groundwater and vapors to move readily through the aquifer and vadose zone.

Each SVE well will be installed to a depth just above the saturated zone, and the AS wells will be installed below the saturated zone. The AS wells are used to inject air into the subsurface to volatilize contaminants from the groundwater. As the contaminants are volatilized, the SVE wells are used to extract the vapors from the vadose zone. The air exchange is handled through a series of pipes that are connected to a remediation system at the ground surface. All air injection and extraction equipment will be housed in a small remediation trailer, along with data components that will allow for the continuous monitoring of the system through telemetry.

The operation pattern for the SVE/AS wells will be adjusted to achieve maximum mass removal of the contaminant from soil. Options include operating all wells simultaneously or operating them in rotation. Analytical data collected during monitoring and maintenance events will be analyzed to determine the best operation pattern. Adjustments to the system will be made during these events.

Air volumes and analytical data for the air effluent will be measured to determine the mass quantity of the contaminant that is being removed. When the data indicate that contaminant (or mass) removal has reached an asymptotic level, the system will be re-evaluated. Soil sampling to determine whether the carbon tetrachloride concentrations are below $200 \mu \mathrm{g} / \mathrm{kg}$ will 
be conducted when asymptotic levels have been reached or the system has been operating for a two-year period. To monitor the effect of remediation on groundwater, samples will be collected quarterly.

\subsection{Site Work}

These specifications and drawings include materials, equipment, and tools that are related to or are to be incorporated in this project, and that must be received, unloaded, stored, installed, erected, service connections provided for, and/or coordinated with the construction by GreenField Contractors. Installation of equipment and materials shall mean furnishing all labor and materials as required for construction of the improvements. GreenField Contractors shall be responsible for all equipment and materials and shall replace all such equipment and materials found defective in manufacture, or damaged in handling after delivery by the manufacturer. All equipment and materials shall be installed in strict accordance with manufacturers’ instructions.

These specifications shall include minor items not specifically mentioned herein, but shown on accompanying plans, or obviously necessary to provide a workmanlike and complete job.

The following description, while not intended to cover all details, outlines major items of work to be accomplished:

- Mobilization and demobilization to and from the site.

- $\quad$ Protection or replacement of existing structures and utilities.

- Installation of five large-diameter boring soil vapor extraction/air sparging (SVE/AS) well sets.

- Conduct short flow and pressure test of SVE and AS wells (discussed in Appendix A).

- Prepare final equipment specifications based on design testing (discussed in Appendix B). 
- Excavation of all piping and utility trenches.

- Installation and backfill of SVE and AS pipelines in trenches.

- Site restoration to include conditions equal to or better than the start of work.

- Installation of SVE and AS equipment and enclosure, hookup to SVE and AS pipelines, and provision of power drop and communication line to system enclosure.

- $\quad$ Provision of any and all required construction permits.

\subsection{Well Installation}

\subsubsection{Large-Diameter Borehole SVEIAS Well Installation}

Five LDBs will be installed at the site by GreenField Contractors in accordance with the design specifications included in the Argonne document Interim Measure Conceptual Design for Remediation of Source Area Contamination at Agra, Kansas, dated July 2007. Each of the wells will be installed using a pier type rig suitable for installation of 6-ft-diameter borings. Each of the borings will be advanced to a depth of approximately $60 \mathrm{ft}$ (approximately 15-20 ft into the aquifer), at which depth the SVE and AS well casings will be suspended in the borings, and the boring will be backfilled with coarse sand. The SVE well casing will be installed above groundwater. The AS well casing will be installed in groundwater. Screen intervals for both wells will be determined during drilling. Fill sand will be brought up to a depth of approximately $7.5 \mathrm{ft}$ below ground surface. A bentonite plug with a minimum thickness of $3 \mathrm{ft}$ will be placed above to provide a surface seal. Clean topsoil will be placed above the sand to the surface. A minimum 12-in.-square, traffic-rated manhole will be placed around the well casing and completed flush with the ground surface.

Before fill sand and topsoil are placed in the LDBs and trenches, approximately six samples will be collected at the sand pit from the sand and topsoil stockpile and analyzed for the following constituents: volatile organic compounds (VOCs), semi-volatile organic compounds, total petroleum hydrocarbons (both diesel range organics and gasoline range organics), and 
metals regulated under the Resource Conservation and Recovery Act (RCRA) (including arsenic, barium, cadmium, chromium, lead, mercury, selenium, and silver). Five additional samples (approximately one sample per five truckloads) will be collected from the fill material as it is hauled and dumped at the site. In addition, a photoionization detector (PID) will be used for field-screening of the sand and topsoil as they are brought to the site. Samples will be collected in a way that ensures that they are representative of the full lateral and vertical extent of the stockpile material to be used as backfill.

Soils extracted during the drilling process will be placed, in the short term, in an unlined, bermed area immediately adjacent to each borehole. Upon completion of the borehole, both extracted soils and berm material next to the borehole will be excavated to a depth of approximately $4.5 \mathrm{ft}$. The excavated material will be placed in the lined landfarming area discussed in Section 2.3. Soil samples for VOCs analyses will be collected from the base and sidewalls of the excavation at each borehole to verify that all soil contaminated at concentrations above the KDHE standard has been removed from the area. Excavated areas will be filled and compacted with soil that has been tested for the compounds of interest. This procedure was suggested and approved by the KDHE. ${ }^{2}$

\subsubsection{Monitoring Well Installation}

Five additional 1-in. or 2-in. monitoring wells (GW-1, GW-2, GW-3, GW-4, GW-5) will be installed by Argonne National Laboratory as shown on the site area map (Drawing Argonne-1). Each of the monitoring wells will be installed with a cone penetrometer unit. Except as noted herein, all well installations shall be performed in accordance with KDHE regulations. Discrete soil samples shall be collected to complete the log of the boring. A Kansas-licensed geologist shall be on-site during all drilling and well completion activities.

Wells will be installed to depths that have historically shown the highest concentrations of carbon tetrachloride. Data indicate that this is approximately $55 \mathrm{ft}$ deep. The well casing shall be installed in stable boreholes after reaching the desired depth. Well casing will consist of 1-in. or 2-in. Schedule 40 polyvinyl chloride (PVC) with $10 \mathrm{ft}$ of 0.10 slotted screen placed at the bottom of the borehole. The filter pack shall be placed in the borehole to a minimum of $2 \mathrm{ft}$

2 KDHE, 2008a, electronic mail message from B. Finzer (Bureau of Environmental Remediation, Kansas Department of Health and Environment, Topeka, Kansas) to L. Larsen (Larsen and Associates, Lawrence, Kansas), regarding requirements for landfarming at Agra, October 13. 
above the top of well screen. The bentonite seal shall be placed in the borehole to a minimum thickness of $3 \mathrm{ft}$ or as indicated on Drawing 5.1.4. The bentonite shall be hydrated with water and allowed to swell before the void above the seal is grouted.

The bentonite-cement grout shall be placed by tremie methods. The tremie pipe shall be inserted to just above the hydrated bentonite and the borehole filled with grout, displacing any water or drilling fluid.

The wells shall be completed with flush-mounted covers unless indicated otherwise on Drawing 5.1.4. Argonne shall obtain the appropriate waiver from the KDHE Bureau of Water, as necessary. Water well record form WWC-5 shall be completed by Argonne for all wells completed into the water table.

All wells completed into the water table shall be developed by pumping and surging until the water from the well is free of fine sand, silt, or other fine particles; $\mathrm{pH}$, temperature, and conductivity measurements of the water have stabilized; or for a period of $2 \mathrm{hr}$, whichever occurs first. The monitoring well installation shall not be developed until a minimum of $24 \mathrm{hr}$ after completion of grouting. Developed water from the wells shall be treated or disposed in a manner that meets all city, county, state, and federal requirements.

\subsection{Landfarming}

Contaminated soils generated during the installation of the wells will be landfarmed onsite. GreenField Contractors has completed and submitted an application to the KDHE for authorization to landfarm the contaminated soils at the site. That application has been approved, and an authorization letter has been issued. ${ }^{3}$ The landfarming area will be prepared by constructing a 2 -ft dike of native soil on the edges to prevent any runoff. Soil from each LDB will be spread over the landfarm area in a 0.5 -ft lift.

3 KDHE 2008b, letter from A. Fink (Solid Waste Processing Unit, Solid Waste Permit Section, Bureau of Waste Management, Kansas Department of Health and Environment, Topeka, Kansas) to J. Peckham (GreenField Contractors, Inc., Salina, Kansas), regarding authorization to landfarm soil at Agra, October 16. 
Below are the operating parameters informally set by the KDHE-Bureau of Waste Management ${ }^{4}$ in order for the landfarming option to be considered for approval. These points are in addition to any standard requirements set forth in the application to landfarm without a permit. The required operating parameters are as follows:

1. Use a PID to field-screen the material as it comes out of the borehole. If the PID readings indicate a high screening level, then collect a soil sample for analysis, and segregate this soil until the analytical results are received. (Argonne will have a PID on-site for these readings.)

2. Use a heavy-duty (6-mil) Visqueen liner (http://www.visqueenbuilding.co.uk/ index.asp). The liner may be overlapping and will not require a seam.

3. Stockpile the soil from each LDB separately on the Visqueen liner. Collect a single soil sample from each LDB before the soil is spread out. The material derived from the drilling of the LDB cannot be spread until the analytical results indicate that it is non-hazardous. Each sample must be analyzed for carbon tetrachloride, chloroform, 1,2-dichloroethane (1,2-DCA), and vinyl chloride. (Argonne will collect and analyze the samples with 24-hr turnaround time.)

4. If the individual total concentrations of carbon tetrachloride, chloroform, and 1,2-DCA do not exceed $10 \mathrm{mg} / \mathrm{kg}$ and if the total concentration of vinyl chloride does not exceed $4 \mathrm{mg} / \mathrm{kg}$, then the soil will be considered non-hazardous and can be landfarmed. If the total concentration of any compound exceeds the standard, then additional testing must be conducted according to the Toxicity Characteristic Leaching Procedure (TCLP) to determine whether the soil is a hazardous waste as defined under RCRA (40 CFR Part 261). The RCRA hazardous waste standards are $0.5 \mathrm{mgL}$ for both carbon tetrachloride and 1,2-DCA, $6 \mathrm{mg} / \mathrm{L}$ for chloroform, and $0.2 \mathrm{mg} / \mathrm{L}$ for vinyl chloride. If any of the soil meets the definition of a hazardous waste under RCRA, then it will be segregated, handled, and disposed of in accordance with RCRA requirements.

4 KDHE, 2008c, electronic mail message from J. Cronin (Solid Waste Processing and Planning Unit, Solid Waste Permit Section, Bureau of Waste Management, Kansas Department of Health and Environment, Topeka, Kansas) to L. Larsen (Larsen and Associates, Lawrence, Kansas), regarding criteria for approval of landfarming at the Agra site, October 8. 
This includes transportation and disposal of the soil at a facility permitted to handle and store hazardous waste. ${ }^{5}$

5. At the end of the landfarming project, divide the area into five grid spaces, and collect one soil sample for VOCs analyses from each grid space. The landfarm may be dismantled in accordance with specifications in the application to landfarm without a permit when the contaminant concentrations do not exceed the following KDHE risk-based standards: carbon tetrachloride $0.2 \mathrm{mg} / \mathrm{kg}$, chloroform $0.96 \mathrm{mg} / \mathrm{kg}, 1,2-\mathrm{DCA} 0.04 \mathrm{mg} / \mathrm{kg}$, and vinyl chloride $0.02 \mathrm{mg} / \mathrm{kg}$.

6. No homes may be located within $500 \mathrm{ft}$ of the landfarm.

7. The KDHE-Bureau of Waste Management application to landfarm without a permit and all required documentation must be submitted to acquire approval for the landfarming. (Landfarming was subsequently authorized.)

Based on approximately 414 cubic yards (11,200 cubic feet) of potentially impacted soils, a landfarming area of approximately $150 \mathrm{ft} \times 150 \mathrm{ft}$ will be required. On a monthly basis, the landfarmed soils shall be disked or otherwise worked to a depth of $0.5 \mathrm{ft}$ to promote aeration, unless the soils are frozen or too wet to allow for tractor operation.

\subsection{Piping and Trenching}

Upon completion of the backfilling of trenches, the entire work area shall be graded to provide adequate drainage and to present a neat and workmanlike appearance.

All excess excavated materials (excluding any contaminated soil), together with all debris, junk, stones, logs, stumps, roots, and other unsuitable materials, shall be removed from the site and disposed of by the contractor at a facility or location that is authorized by the KDHE to accept the debris and materials. Grading and surfacing shall be completed to the satisfaction of the owner/operator's representative.

5 KDHE, 2008d, electronic mail message from A. Fink (Solid Waste Processing and Planning Unit, Bureau of Waste Management, Kansas Department of Health and Environment, Topeka, Kansas) to L. Larsen (Larsen and Associates, Lawrence, Kansas), regarding hazardous waste definition and TCLP testing in relation to landfarming at the Agra site, October 23. 


\subsubsection{Trenching}

Proposed locations for the remediation trailer and trenches are shown in Drawing Argonne-1. Trenching shall be performed by a contractor using a backhoe or trenching machine suitable for the depth of excavation and type of material to be excavated. All trenches will be excavated to depths and grades shown on the drawings or to depths required to accomplish the work. All SVE piping shall slope a minimum of 0.25 in. per foot toward the SVE wells, where possible. At no time should the trenches exceed a depth of $5 \mathrm{ft}$ at the wellheads.

Excavated soil that is not contaminated will be used as backfill. All excavated material that is not appropriate for use as backfill shall be disposed or treated as outlined in Sections 2.3 and 2.4. Soil that exceeds the KDHE remediation guidelines shall be placed in the landfarm and aerated. Soils with carbon tetrachloride concentrations exceeding $200 \mu \mathrm{g} / \mathrm{kg}$ must be handled as described in Section 2.3.

Trenches for pipelines and electrical conduit shall be not less than 4 in. or more than 18 in. wider than the outside diameter of the pipe(s) to be laid therein. Excavation for manholes and other accessories shall have 12 in. minimum and 24 in. maximum clearance on all sides.

Any unauthorized over-excavation shall be backfilled with sand or similar natural materials if free of clods or gravel larger than 1/4 in. diameter. Pipe shall not be placed on frozen soil or other soil that may damage the pipe.

Temporary support, adequate protection, and maintenance of all underground and surface

utility structures, drains, sewers, and other obstructions encountered in the progress of the work shall be furnished by the contractor.

\subsubsection{Temporary Trench Crossing}

Temporary bridges of crossings over the trench shall be built and maintained by the contractor where required to maintain traffic. 


\subsubsection{Excavation-Competent Person}

A competent person who has 40-hr Occupational Safety and Health Administration (OSHA) training and OSHA site supervisor training; who is capable of identifying existing and predictable hazards or working conditions that are hazardous, unsanitary, or dangerous to the employees; and who has authorization to take prompt corrective measures to eliminate or control these hazards and conditions, shall evaluate all trenches before workers can enter them. Excavations greater than $4 \mathrm{ft}$ in depth, as well as ones where oxygen deficiency or a hazardous atmosphere exists or could reasonably be expected to exist, must be tested to assure a safe atmosphere before entry is made. Evaluations must be documented. All trenches, excavations, and boreholes will be properly flagged and/or marked. Safe means for employees to enter and exit an excavation or trench will be provided.

\subsubsection{Backfilling}

After the pipe joints are set and approved, required pressure testing and inspections must be conducted prior to backfilling. Backfilling shall be carefully performed and the surface brought to existing grade or the elevations shown on the plans.

Backfilling shall be performed with selected material as specified in Drawing 5.1.3D, sufficiently damp to be properly compacted in layers not exceeding 6 in. in thickness. Compaction shall be performed with mechanical tampers and continued until an in-place density of $90 \%$ of standard density, in conformance with ASTM D 698, is attained or the site project licensed engineer inspects and approves the compaction. If Proctor testing is conducted, a certified geotechnical laboratory will conduct the test.

\subsubsection{Piping}

Pipelines, fittings, and valves not otherwise specified shall conform to the specifications set forth in this section. All pipe, valves, fittings, and appurtenances shall be new material unless otherwise specified. Any section of pipe already laid and found to be defective shall be taken up and replaced. 


\subsubsection{Polyvinyl Chloride Pipe}

The PVC pipe 4 in. and smaller shall be made in accordance with and shall conform to ASTM 1784, Type 1, Grade 1, for PVC Compounds; ASTM D2466 for PVC pressure fittings. Fittings used in vacuum service may be PVC DWV fittings conforming to ASTM D2665.

\subsubsection{Classification}

The PVC pipe shall conform to ASTM 1785 and ASTM D2241, suited for working pressure of $150 \mathrm{psi}$ at $73^{\circ} \mathrm{F}$.

\subsubsection{Test Requirements}

The manufacturer shall certify in writing, upon request, that the pipe and couplings furnished comply with the following:

1. Specifications set forth above

2. Hydrostatic tests

3. Flexural tests

\subsubsection{Manufacture and Testing}

All PVC pipe shall be manufactured and tested within the continental limits of the United States.

\subsubsection{Construction Methods}

Each section of pipe bedded in trenches in soil, sand, or gravel, shall rest upon the pipe bed for the full length of its barrel. Any pipe that has its grade disturbed after laying shall be taken up and re-laid. The interior of all pipes shall be thoroughly cleaned of all foreign matter before being lowered into the trench, and shall be kept clean during laying operation by means of 
plugs or other approved methods. Under no circumstances shall pipe be laid in water, and no pipe shall be laid when trench or weather conditions are unsuitable for such work. In all cases water shall be kept out of the trench until the material in the joints has hardened.

\subsubsection{Pipe Installation}

Installation of PVC pipe shall be in accordance with ASTM D2774 specified herein.

- Handling: Pipe and accessories shall be handled in such a manner as to ensure delivery to the work in sound, undamaged condition. No other pipe or material of any kind shall be placed inside of any pipe or fitting.

- Cutting: Cutting of pipe shall be done in a neat and workmanlike manner by a method that will not damage the pipe. Unless otherwise authorized, all cutting shall be done by means of mechanical cutters of an approved type. Wheel cutters shall be used whenever practical.

- Placing and Laying: Before lowering and while suspended, pipe shall be inspected for defects and cracks. Defective, damaged, or unsound pipe shall be rejected. Prior to laying, the pipe bedding material shall be placed by slicing with a shovel and mechanical tamping, according to the type of material.

- Joints: All joints shall be socket-type fitting and shall be solvent cemented in conformance with ASTM D2855. The PVC primer shall meet the requirements of ASTM F656. The solvent cement shall meet the requirements of ASTM D2564.

- Pressure Testing: All pipes will be pressure-tested for leaks before the trenches are backfilled. Any piping found to exhibit a leak will be repaired or replaced. Data from the tests will be included in the remedial installation report. 


\subsection{Electrical Work}

The electrical contractor shall obtain all permits and inspection required for the installation of the electrical work. The electrical contractor shall furnish all labor, tools, transportation, equipment, services, and facilities required to install a complete and workable electrical system. The services of a licensed electrician are required.

All conduit exposed to the weather shall be galvanized, rigid steel conduit. Such conduit shall be located in a manner to minimize potential for vandalism. Conduit installed in soil shall be either galvanized steel conduit or Schedule 40 PVC. If PVC is used, the riser and conduit within $3 \mathrm{ft}$ of the riser shall be galvanized steel conduit. All electrical lines shall be buried to the maximum extent possible.

The licensed electrical contractor shall have a metered electrical service established and extended to the treatment area. The service shall be sufficient to supply the maximum electrical demand of all equipment, lights, and heating equipment installed in the system enclosure, plus an excess capacity of $20 \%$ of the proposed demand. A junction box with circuit breakers shall be located immediately below or adjacent to the metered service from the electric company or in another accessible area.

The electrical contractor shall follow the equipment suppliers' and manufacturers' specifications and recommendations for the installation and completion of electrical work. Electrical installation shall be in conformance with all applicable codes and acceptable industry standards. All electrical equipment and components, including research and development equipment, will be labeled or listed by a nationally recognized testing laboratory (NRTL) or be field evaluated and approved by a designated electrical equipment inspector prior to use. All newly acquired electrical equipment will be NRTL listed if such equipment is available. Each service, feeder, and branch circuit at its disconnecting means, or overcurrent device, will be legibly marked to indicate its purpose unless located and arranged so the purpose is evident. These markings shall be of sufficient durability to withstand the environment involved.

Ground rods shall be 3/4-in. diameter, 10-ft long, copper-clad steel or copper alloy, sectional type rods with one end pointed to facilitate driving. The electrical contractor shall install ground rods by driving them into the ground. The ground rods shall be placed into natural 
soil where possible. Where rods must be installed in excavation areas, drive rods into earth after compaction of backfill is completed.

\subsection{Equipment Specifications for SVEIAS System}

This section describes the major pieces of equipment and general operational performance requirements. The specifications within this document are representative of similar systems installed at similar sites. However, final design decisions will be made based on performance testing the LDBs following installation. The revised design will be submitted for review prior to purchase and installation of the remedial equipment. Small items not specifically addressed shall be supplied with and be compatible with the system.

The SVE and AS components shall be installed in a trailer that is insulated and vented. The trailer will be located on the west side of the property, near the overhead electrical lines. All controls shall be located to prevent vandalism or tampering. The placement of the equipment in the enclosure shall be designed for easy access and maintenance of the equipment. A process and instrumentation diagram is attached as Drawing 5.1.2A.

\subsubsection{SVE Components}

The SVE system shall have the capacity to operate continuously, $24 \mathrm{hr}$ per day, 7 days per week, and shall be designed for unattended operation.

1. The SVE system shall include a moisture separator (knockout) tank, a Rotron Model \#MS350B or equivalent. Although a transfer pump and level controls are not included in the design, the system should be capable of later installation if required. The knockout tank will include the following:

- Inlet, 4-in. diameter or greater

- $\quad$ Steel National Pipe Thread (NPT) air outlet, 4 in. in diameter or greater

- $\quad$ Steel 1-in. NPT manual drain water valve 
- High-level switch

- Sight gauge

2. A Rotron Model No. EN707F72MXL regenerative blower or equivalent will be powered by a minimum 5-horsepower, 230/460-volt, 3-phase motor. If 3-phase power is not available, all motors will be single phase. The motor shall be equipped with a built-in thermostat to shut off the motor if the motor overheats.

3. The SVE system shall include a 10-micron inline filter between the knockout tank and blower, sized to operate at the designed flow rate. The filter shall be a Solberg Model CSL-851-250HC or equivalent.

4. The SVE system shall include a dilution air intake controlled by a manual air dilution valve and silencer. These will be mounted upstream of the in-line air particulate filter.

5. An automatic vacuum relief valve shall be installed at the blower inlet. The valve shall be a Rotron Part No. 551027 or equivalent.

6. A vacuum gauge (0-60 in. of water) shall be mounted on the SVE piping upstream of the flow meters. The system shall also have vacuum gauges before and after the inline filter to monitor differential pressure across the filter.

7. An intrinsically safe high-water-level switch shall be mounted on the knockout tank. The high-water-level switch shall be a Madison Model M8700 or equivalent.

8. A five-well SVE manifold will be installed upstream of the moisture separator. Each leg of the manifold will contain a 2-in. PVC ball valve, a variable-area (Rota meter) type flow meter, a steel quick-connect port, a sample port (0.25-in. ball valve), and a vacuum gauge. The manifold will also include a blowback system to allow use of the blower discharge to blow 
moisture from the SVE lines during routine operation and maintenance activities.

9. The vapor flow meters shall be mounted on each SVE line in a position for unobstructed readout. The flow meter shall have an operating range of 8-80 scfm and shall be a variable-area flow rate indicator. The flow meter shall be a Blue-White F-451 or equivalent.

10. A vacuum blower discharge silencer shall be included for noise reduction. The discharge stack shall be steel, with a minimum height of $20 \mathrm{ft}$ above grade, or as required by applicable permits.

11. A granular activated carbon system to treat condensate is not included in the original design. The SVE system will be monitored after installation to determine whether this additional equipment is needed. The equipment will be installed only if it is determined to be necessary.

\subsubsection{AS System}

The AS system shall have the capacity to operate continuously, 24 hr per day, 7 days per week, and shall be designed for unattended operation. The AS blower is sized to allow for the installation of additional AS wells if required. An AS system capable of injecting air at a minimum flow rate of $25 \mathrm{scfm}$ at 12 psi is specified.

1. The compressor will be powered by a 5-horsepower, 230/460, 3-phase motor. If 3-phase power is not available, all motors will be single phase. The compressor shall be equipped with an integral pressure relief valve. The motor shall be equipped with a built-in thermostat to shut off the motor if the motor overheats. The compressor will be a Rietschle DLT 40 Oil-less Rotary Vane Compressor, or equal.

2. A manual by-pass air valve with silencer shall be provided on the pressure side of the compressor to assist in controlling the air flow and pressure to the air sparge wells. 
3. A pressure gauge with a range of $0-15$ psig shall be mounted at the compressor outlet to monitor discharge pressure. The gauge will read in units of psig.

4. An intake filter/silencer shall be included for noise reduction. The filter shall be a 10-micron media particulate filter, mounted before the compressor inlet. The intake filter will be a Gast Model \# AJ134C, or equal.

5. A five-well AS manifold constructed of 1-in. (trunk line) and 0.5-in. (individual legs) steel pipe will be installed downstream of the compressor. Each leg of the manifold will include a 0.5-in. brass gate valve, a flow meter, steel quick connect and a 0-30 psi pressure gauge.

6. The flow meters shall be variable-area (Rota meter) type flow meters with a range of 1-12 scfm. The flow meters shall be Blue-White Model F-450, or equal.

7. A Deihl Series 882 timer or equal, programmable to 15-min intervals, shall be provided and mounted in the control panel for operation of the AS compressor.

\subsubsection{Equipment Enclosure and Controls}

The equipment shall be located inside a double-axle cargo trailer. The existing surface shall be appropriately graded such that the equipment enclosure will be level.

1. The trailer enclosure shall be a minimum of $12 \mathrm{ft}$ long by $6 \mathrm{ft}$ wide by $6 \mathrm{ft}$ tall.

2. The trailer enclosure shall be fitted with sufficient heat exhaust fans or power vents. The exhaust fan or power ventilator and vents shall be side mounted.

3. A control panel and main disconnect and breaker will be mounted on the outside of the trailer enclosure for power and environmental control. Each 
component shall be lockable. One duplex outlet will be located in the control panel.

4. The control panel will be a NEMA-3R panel with on/off/auto switches to control the AS unit and the SVE unit. The panel will also include green system run lights and separate hour meters for both the AS and SVE units. The AS compressor will be interlocked with the SVE blower to prevent operation when the SVE blower in not in operation. The SVE system will shut down under high water level conditions in the knockout tank. Allowances shall be made for the potential addition of a knockout tank transfer pump and level controls should they be required. The control panel will incorporate an auto-dialer capable of dialing out to a minimum of eight separate numbers in an alarm condition or to retrieve system status.

5. A heater and insulation shall be provided, sufficient to maintain a minimum temperature of $40^{\circ} \mathrm{F}$ inside the enclosure when the outside temperature is $-10^{\circ} \mathrm{F}$ and the equipment is not in operation.

\subsection{Remedial Plans}

The following drawings are at the end of the document:

- Drawing 5.1.0 Cover Sheet

- Drawing Argonne-1 Proposed Locations for Remediation Trailer and Trench Lines

- Drawing 5.1.2A Process and Instrumentation Diagram Legend

- Drawing 5.1.2B Soil Vapor Extraction Process and Instrumentation Diagram

- Drawing 5.1.2C Air Sparge Process and Instrumentation Diagram 
- Drawing 5.1.3A Equipment Layout Details

- Drawing 5.1.3B S Soil Vapor Extraction Manifold Details

- Drawing 5.1.3C Air Sparge Manifold Details

- Drawing 5.1.3D Miscellaneous Details

- Drawing 5.1.4 SVE and Air Sparge Well Details

- Drawing 5.2.1A Electrical Legend

- Drawing 5.2.1B Remediation System Electrical Schematic

- Drawing 5.2.1C Auto-Dialer Alarm Logic

- Drawing 5.2.1D Electrical One-Line Wiring Diagram 


\section{Operation, Maintenance, and Monitoring Specifications}

\subsection{System Start-up}

- GreenField Contractors shall be responsible for starting, operating, maintaining, and monitoring the remediation system.

- Prior to start-up, GreenField Contractors shall inspect all available piping connections, valve settings, and electrical connections. All motors shall be tested for proper rotation, voltage, and amperage draw. The control system shall be tested to ensure that the system operates as designed, including the creation of system faults to verify system programming.

\subsection{Start-up Procedures}

\subsubsection{SVE Start-up}

- Check the position of all valves and switches.

- Start SVE system with the by-pass valve completely open to prevent surges from damaging the vacuum gauges. Check motor rotation direction and amperage draw and compare with equipment specifications to ensure proper operation. Confirm vacuum and flow of individual SVE wells at main system gauges.

- Slowly shut the by-pass valve and check the vacuum gauges at the header to ensure the wells are connected properly. Start system operating on three wells (SVE-1, SVE-3, and SVE-4). Increase the vacuum applied to these wells, and balance the flow rates between the wells by adjusting the valves. Confirm vapor extraction rates as determined by the design testing, using inline flow meters. Compare applied vacuum at the wellhead with that recorded at the header gauges. Record all system readings. During start-up, SVE wells will be 
operated on an alternating basis based on the results of the field readings collected during system operation.

- Field-screen the air effluent from each well and the discharge line by using a PID or equivalent approved method. Collect air samples from the effluent sample port and submit samples for U.S. Environmental Protection Agency (EPA) Method TO 14.

- Program and test the auto-dialer and check hour meters to ensure operation. Check the air sparge interlocks to ensure that the air sparge blower will not operate unless the SVE system is operational. Test the high-level alarm in the knockout tank.

- Check for liquid accumulating in the moisture separator. If significant water accumulates in a short period, extend evaluation to determine long-term liquid accumulation rate relative to extraction rates.

- Operate the SVE system for a minimum period of one month prior to AS system start-up to confirm the capture zone of the SVE system.

\subsubsection{AS Start-up}

Following SVE system operation for a period of one month, and with LEL readings at $10 \%$ or less, the AS system shall be started. Initially, the AS wells will be operated to optimize performance based on the recommendation resulting from the design testing.

- Measure baseline dissolved oxygen (DO) concentrations in each of the AS wells; monitoring wells MW-P and MW-R; and proposed wells GW-1, GW-2, GW-3, GW-4, and GW-5.

- Check the position of all valves and switches. Start the AS system with the bypass valve fully open to prevent surges from damaging the gauges. Check motor direction and amperage draw and compare to equipment specifications 
to ensure proper operation. Confirm air pressure and flow readings at main system gauges.

- Set AS blower to operate on a $4 \mathrm{hr}$ on/2 hr off cycle. Slowly shut the by-pass valve and check pressure and flow at the header gauges to ensure that the wells are properly connected. Increase the pressure applied to each well to achieve the specified flow rate and inspect for leaks. Balance the flow rate for each well by adjusting the valves and record all system gauge readings. Confirm flow rates of $5 \mathrm{scfm}$ at each AS wellhead by measuring flow at the inline flow meters. Compare applied pressures at the wellhead with that recorded at the header gauges. Record all system readings. Reset flow rates to those determined by the design testing.

- Collect PID readings from each SVE following AS system startup and record baseline.

\subsection{Operation and Maintenance Requirements}

\subsubsection{Weekly Maintenance}

- System faults or failure conditions should be reported by the auto-dialer system. GreenField Contractors must visit the site, correct the problem, and restart the system.

- During any site visit, GreenField Contractors shall inspect the system to identify problems and prevent future malfunctions indicated by abnormal operating conditions. Preventative maintenance shall include, but is not limited to, inspection of all gauges, filters, and system operating parameters. 


\subsubsection{Monthly Maintenance and Monitoring}

- GreenField Contractors shall visit the site on a monthly basis to field-screen air samples collected from each SVE well and effluent line by using a PID or equivalent approved method.

- During the initial six months of operation, all five SVE wells will be operated simultaneously. The system will be monitored, and changes in the operating parameters will be made as site conditions warrant. After six months of operation, evaluate monitoring results to revise and optimize operation of the SVE wells. This operation sequence is subject to change based on the results of the design testing.

- GreenField Contractors shall field-screen the combined SVE effluent prior to the dilution valve for $\mathrm{O}_{2}$ by using an oxygen meter, and for carbon tetrachloride and chloroform by using colorimetric tubes or other approved methods.

- GreenField Contractors shall field-screen the extracted vapors from individual SVE wells for $\mathrm{O}_{2}$ by using an oxygen meter, and carbon tetrachloride and chloroform by using colorimetric tubes or other approved methods.

- Check all gauges and hour meters and record readings. Measure and record wellhead vacuum and pressure readings from each SVE and AS well.

- Adjust well flow rates, based on contaminant levels, to optimize system performance.

- GreenField Contractors shall conduct any other sampling or monitoring activities required by the KDHE for the SVE/AS system. This includes recording static groundwater levels.

- GreenField Contractors shall conduct any manufacturer-recommended maintenance. 


\subsubsection{Quarterly Maintenance, Operation, and Monitoring}

- Measure and record vacuum, pressure, and flow rates at all SVE and AS wells. Measure wellhead vacuum readings at MW-P and proposed GW-1, GW-2, GW-3, GW-4, and GW-5. Measure DO at MW-P and proposed GW-1. Gauge, purge, and sample monitoring wells MW-J and MW-P and proposed wells GW-1, GW-2, GW-3, GW-4, and GW-5. Submit groundwater samples to the Applied Geosciences and Environmental Management Laboratory at Argonne or to a Kansas-certified laboratory for analysis for VOCs by EPA Method 8260. Measure and record field DO levels at all wells.

- Collect air samples from the effluent sample port, and analyze the samples according to EPA Method TO 14.

- Perform all monthly operation, maintenance, and monitoring requirements.

\subsection{Permits}

GreenField Contractors shall furnish all state, city, county, local and federal building permits and all property easements that are required for construction of this system.

Based upon the design parameters of this system, effluent discharge is anticipated to be de minimis, requiring no air discharge permit; however, the required air discharge notification form will be completed and submitted to the KDHE Bureau of Air and Radiation. A Class V injection permit will be required for implementation of the AS system. A Class V injection well permit is a miscellaneous category of injection well permit designed for remediation-type wells.

Additional permitting will be required for operation of the landfarm. GreenField Contractors shall verify that all permits required are approved and in place before operating the soil remediation system. 


\subsection{Winterization}

Winterization of the remediation system shall be accomplished by placing equipment that would be subject to freezing inside the heated trailer enclosure. Exposed SVE flow line piping shall be insulated to minimize condensation and freezing potential during cold weather.

\subsection{Property Restoration}

Debris resulting from construction activities at the site shall be removed from the site and disposed of at a licensed construction demolition landfill or other approved facility.

Where applicable, all driveways, roadways, parking lots, yards, fences, and other property shall be restored to the original condition. Grading, surfacing, and other types of property restoration shall be completed to the satisfaction of the owner/operator or a designated representative.

Property conditions before, during, and after construction activities are to be documented with color photographs. A copy of the photographic record shall be provided with the remedial installation report.

\subsection{Labor}

GreenField Contractors shall supply, either directly or by subcontractor, all other staff necessary to implement this project. The other staff shall include, but not be limited to, accounting personnel, environmental technicians, laboratory services, and general labor to complete and operate the remediation system.

The GreenField field staff includes the following individuals:

- Tim Pace — president and remediation director

- Royce Face - engineer 
- John Peckham — environmental scientist and health and safety officer

- Bill Serrault — construction manager

- Mike Milleson — environmental technician

- MO-KAN — drilling company providing driller and driller helper

The Argonne National Laboratory staff and contract staff include the following individuals:

- Lorraine M. LaFreniere — geologist and project manager

- Bob Sedivy —hydrologist

- Lisa Larsen — geologist

- Monte Brandner — Argonne safety specialist

- David Surgnier — engineer

The TCW, Inc., staff member is as follows:

- Travis Kamler — cone penetrometer operator and logistics support

\subsection{Schedule and Reporting}

The detailed schedule for operations, maintenance, and monitoring is in Appendix F. A remedial installation report will be submitted within 60 days following system start-up. This report will include all as-built drawings, a system operation and maintenance manual, and engineering start-up and pilot test data. 


\section{Appendix A:}

\section{Data Acquisition Plan - Design Testing Requirements}




\section{Appendix A:}

\section{Data Acquisition Plan - Design Testing Requirements}

To accurately size SVE and AS equipment, a series of short vacuum extraction and AS tests will be conducted on the LDBs following their installation. The SVE testing will be conducted with a mobile pilot test unit capable of a minimum of $100 \mathrm{scfm}$ at $40 \mathrm{in}$. of water vacuum (with a maximum vacuum of at least 80 in. of water). The AS testing will be conducted by using a mobile pilot test unit capable of a minimum of $5 \mathrm{scfm}$ at 10 psi. The pilot testing will consist of the testing specified below:

\section{A.1 SVE Testing}

The SVE pilot test will provide the data necessary to determine the appropriate equipment size that is needed to ensure operation of the system at maximum performance. The test will measure the vacuum at each extraction well as various flow rates are applied to the wells.

Each of the SVE wells will be tested as follows:

1. A brief step test will be conducted by operating the SVE wells at various flow rates, $(100 \%$ of the maximum achievable flow, $75 \%$ of the maximum flow, $50 \%$ of the maximum flow, and $25 \%$ of the maximum flow). At each flow rate, the wellhead vacuum of the extraction well will be measured and recorded.

2. Vacuum response measurements will be collected at each of the adjacent SVE wells during each of the flow steps.

3. Each step will be conducted for a minimum of $5 \mathrm{~min}$, until vacuum responses in adjacent SVE wells equilibrate, or for a maximum of $15 \mathrm{~min}$.

4. At least one vapor sample will be collected during the testing at each well and analyzed in the field for oxygen, carbon dioxide, and VOCs (by using a PID). 
Air samples from each SVE well will also be analyzed in the laboratory according to EPA Method TO 14.

\section{A.2 AS Testing}

Short AS tests will be conducted at each of the AS wells to confirm the required injection pressures to achieve flow rates of $5 \mathrm{scfm}$.

Flow rates, vapor rates, and vacuum responses recorded during testing will be used to evaluate system effectiveness. Based on the results of the design testing, a brief summary report will be prepared. This report will include final system design details including SVE and AS

blower and component specifications, as well as piping sizes. Calculations used to finalize the design will be included in the summary report. 


\section{Appendix B:}

\section{Basis of Design}




\section{Appendix B:}

\section{Basis of Design}

Section 6.1 of the Interim Measure Conceptual Design for Remediation of Source Area Contamination at Agra, Kansas, dated July 2007, is a summary of the design basis for the installation of the proposed LDB SVE/AS system. The rationale for the selection of the LDBs as a remediation technology, as well as the location and construction of each of the LDBs, is discussed. While the LDB concept is covered in the design document, design parameters required for sizing and selecting the remediation system components will be based on the design testing conducted on the LDBs following their installation. These design components are as follows:

1. Electrical Classification: The remediation system will be configured for use in a Class 1, Division 2 electrical environment as defined in the National Electrical Code (NEC).

2. SVE Blower: The SVE blower will be a regenerative-type blower of sized based on the results of the design test. While maintaining a reasonable size (10 hp or less), the blower will be selected to maximize the vacuum influence of individual SVE wells without pulling a vacuum sufficiently high that excess water production from the SVE wells results. Some flexibility will be inherent in the design so as to economically operate all five wells simultaneously or to operate fewer wells at a higher vacuum and thus maximize vacuum influence of selected wells. At a minimum, the blower will be sized to extract approximately three times the design air flow rate of the AS system, to ensure capture of all AS vapors (a minimum of $75 \mathrm{scfm}$ at $40 \mathrm{in}$. of water will be required).

3. AS Compressor: As the AS wells are being installed in the clean LDB backfill, it is assumed that the operating pressure will be equivalent to the depth of the screen below the water table (approximately 4 psi assuming $10 \mathrm{ft}$ of submergence at a pressure of $0.43 \mathrm{psi} / \mathrm{ft}$ of water). The AS compressor will be sized to operate all of the AS wells simultaneously at a moderate flow rate of $5 \mathrm{scfm} /$ well, or fewer wells at a more aggressive injection rate. The AS 
compressor will be designed to operate on a timer, cycling the injection events to maximize AS effects.

4. Piping: The SVE piping will be sized to minimize the pressure drop between wells and the remediation equipment trailer (approximately $400 \mathrm{ft}$ ), while keeping sufficient velocity (approximately $1,500 \mathrm{ft} / \mathrm{min}$ ) to minimize collection of condensate or co-produced water in the lines. 


\section{Appendix C:}

\section{Permits}




\section{Appendix C:}

\section{Permits}

Permits are to be supplied for this appendix after all approvals have been received. 


\section{Appendix D:}

\section{Quality Assurance Project Plan (QAPP)}




\section{Appendix D:}

\section{Quality Assurance Project Plan}

The Quality Assurance Project Plan (QAPP) for this scope of work is included in the Argonne document Final Master Work Plan: Environmental Investigations at Former CCC/USDA Facilities in Kansas, 2002 Revision. ${ }^{6}$ That Argonne document is on file with the KDHE. The document is cited here rather than included in toto per conversation with the KDHE project manager. ${ }^{7}$

6 Argonne, 2002, Final Master Work Plan: Environmental Investigations at Former CCC/USDA Facilities in Kansas, 2002 Revision, ANL/ER/TR-02/004, prepared for the Commodity Credit Corporation, U.S. Department of Agriculture, Washington, D.C., by Argonne National Laboratory, Argonne, Illinois, December.

7 KDHE, 2008, telephone conversation between E. McWilliams (Bureau of Environmental Remediation, Kansas Department of Health and Environment, Topeka, Kansas) and L. Larsen (Larsen and Associates, Inc., Lawrence, Kansas), June 6. 


\section{Appendix E:}

\section{Health and Safety Plan}




\section{Appendix E:}

\section{Health and Safety Plan}

GreenField has provided detailed health and safety documentation. This documentation has been reviewed and approved by the Argonne health and safety professionals who have responsibility for oversight of the work at Agra. The GreenField plan is complementary to Argonne's site-specific health and safety plan. The complete GreenField documentation is being provided to the KDHE under separate cover.

The approved GreenField documentation includes the following elements:

- Approved Argonne "High Risk Job Safety Analysis"

- "Emergency Procedures/Contingency Plan,” reviewed by GreenField personnel

- GreenField statement that no local or state permits are required for the GreenField portion of the work at Agra

- GreenField "Site Health and Safety Plan: Remediation of Source Area Contamination, Agra, Kansas”

- GreenField safety training certifications

- Record of GreenField crane inspection

- Material safety data sheets for CAT Multipurpose Grease (NLGI \#2), Diesel Fuel No. 2, Oatey PVC Medium Clear Cement, Oatey Clear Cleaner

- GreenField accident and injury summary data report (“Workers Compensation Experience Rating”) 
- The site-specific health and safety plan for Argonne's work at Agra, including list of Argonne contacts and a map showing the route from the work site to Phillips County Hospital in Phillipsburg, Kansas 


\section{Appendix F:}

Operations, Maintenance, and Monitoring Schedule 


\section{Estimated Time Sequence for Source Remediation Implementation at the Former CCC/USDA Property in Agra, Kansas}

\begin{tabular}{|c|c|c|c|c|c|c|}
\hline Activity & Week \# & \begin{tabular}{|c|}
$\begin{array}{c}\text { Frequency, } \\
\text { Timeframe }\end{array}$ \\
\end{tabular} & \begin{tabular}{|c|} 
Description and Locations \\
\end{tabular} & \begin{tabular}{|l} 
Media/Analytes \\
\end{tabular} & Conducted By & Report to USDA / KDHE \\
\hline $\begin{array}{l}\text { Pre-install Baseline } \\
\text { Monitoring }\end{array}$ & 1 & $\begin{array}{l}\text { Once, prior to } \\
\text { installing the LDBs }\end{array}$ & $\begin{array}{l}\text { Collect groundwater samples from existing wells: MW-2, KMW01, KMW02, } \\
\text { KMW03, MW-B, MW-C, MW-F, MW-G, MW-H, MW-I, MW-J, MW-K, MW- } \\
\text { L, MW-M, MW-O, MW-P, MW-Q, MW-R, and SB72. }\end{array}$ & $\begin{array}{l}\text { Groundwater samples } \\
\text { for VOC analyses }\end{array}$ & Argonne & $\begin{array}{l}\text { Included in the Remedial } \\
\text { Installation Report. }\end{array}$ \\
\hline Stockpile Sand & 1 & $\begin{array}{l}\text { Once, prior to LDB } \\
\text { install }\end{array}$ & Stockpile the sand needed for placement in the LDBs. & None & Greenfield & $\begin{array}{l}\text { Included in the Remedial } \\
\text { Installation Report. }\end{array}$ \\
\hline Install LDBs & $2-3$ & Once, 2 weeks & Stockpile sand supply and drill LDB. & None & $\begin{array}{l}\text { Greenfield, } \\
\text { Argonne oversight }\end{array}$ & $\begin{array}{l}\text { Included in the Remedial } \\
\text { Installation Report. }\end{array}$ \\
\hline $\begin{array}{l}\text { SVE / AS Pilot Test and } \\
\text { System Design }\end{array}$ & $4-5$ & Once, 2 weeks & $\begin{array}{l}\text { Conduct pilot test of system to determine the appropriate remediation } \\
\text { equipment sizes. }\end{array}$ & None & $\begin{array}{l}\text { Greenfield, } \\
\text { Argonne oversight }\end{array}$ & $\begin{array}{l}\text { Included in the Remedial } \\
\text { Installation Report. }\end{array}$ \\
\hline $\begin{array}{l}\text { Order Remediation } \\
\text { Equipment and Trailer }\end{array}$ & 6 & Once, 8-10 weeks & $\begin{array}{l}\text { System equipment is ordered from the manufacturer. The equipment is } \\
\text { installed in the trailer. }\end{array}$ & None & Greenfield & $\begin{array}{l}\text { Included in the Remedial } \\
\text { Installation Report. }\end{array}$ \\
\hline $\begin{array}{l}\text { SVE / AS trenching and } \\
\text { piping installation }\end{array}$ & 6-7 & Once, 2 weeks & $\begin{array}{l}\text { Dig trenches and install piping from the SVE/AS wells to the location of the } \\
\text { trailer. }\end{array}$ & None & $\begin{array}{l}\text { Greenfield, } \\
\text { Argonne oversight }\end{array}$ & $\begin{array}{l}\text { Included in the Remedial } \\
\text { Installation Report. }\end{array}$ \\
\hline $\begin{array}{l}\text { Install } 5 \text { monitoring wells } \\
\text { and } 3 \text { soil gas monitoring } \\
\text { wells }\end{array}$ & 8 & Once, 1 week & $\begin{array}{l}\text { Install new monitoring wells GW-1, GW-2, GW-3, GW-4 and GW-5. Well } \\
\text { screen depths will be dependent upon lithology encountered during drilling. } \\
\text { Pending CCC/USDA approval, also install new soil gas monitoring wells SG- } \\
1, \text { SG-2, and SG-3. }\end{array}$ & $\begin{array}{l}\text { Groundwater samples } \\
\text { for VOC analyses }\end{array}$ & Argonne & $\begin{array}{l}\text { Included in the Remedial } \\
\text { Installation Report. }\end{array}$ \\
\hline $\begin{array}{l}\text { Hook up trailer and } \\
\text { remediation equipment }\end{array}$ & $15-16$ & Once, 1 week & Hook up all remediation equipment in the trailer. & None & $\begin{array}{l}\text { Greenfield, } \\
\text { Argonne oversight }\end{array}$ & $\begin{array}{l}\text { Included in the Remedial } \\
\text { Installation Report. }\end{array}$ \\
\hline SVE System Start-up & 17 & $\begin{array}{l}\text { Once, after LDBs, } \\
\text { SVE, and AS } \\
\text { components are } \\
\text { installed. }\end{array}$ & $\begin{array}{l}\text { Inspect all equipment, piping connections, valve settings, electrical } \\
\text { connections. Test all motors for proper rotation, voltage, and amperage } \\
\text { draw. Test control system to ensure it is operating as designed, including } \\
\text { the creation of system faults to verify system programming. }\end{array}$ & $\begin{array}{l}\text { Field screen air } \\
\text { effluent using a PID } \\
\text { for VOCs, and } \\
\text { laboratory test air } \\
\text { effluent samples for } \\
\text { VOCs }\end{array}$ & $\begin{array}{l}\text { Greenfield, } \\
\text { Argonne oversight }\end{array}$ & $\begin{array}{l}\text { Included in the Remedial } \\
\text { Installation Report. }\end{array}$ \\
\hline AS System Start-up & TBD & $\begin{array}{l}\text { Once, after the } \\
\text { SVE has operated } \\
\text { for one month and } \\
\text { the LEL readings is } \\
10 \% \text { or less. }\end{array}$ & $\begin{array}{l}\text { Check all position valves and switches. Fully open bypass valve, check } \\
\text { motor direction and amerage draw and compare to equipment } \\
\text { specifications. Confirm air pressure/flow readings. Set AS blower to cycle } \\
\text { on/off, increase pressure to check for leaks, record gauge readings, confirm } \\
\text { flow rates, compare pressures at wellhead with recorded header gauges, } \\
\text { record all system readings. Reset flow rates to design rates. }\end{array}$ & $\begin{array}{l}\text { Field screen air } \\
\text { effluent using a PID } \\
\text { for VOCs, record for } \\
\text { baseline numbers }\end{array}$ & $\begin{array}{l}\text { Greenfield, } \\
\text { Argonne oversight }\end{array}$ & $\begin{array}{l}\text { Included in the Remedial } \\
\text { Installation Report. }\end{array}$ \\
\hline
\end{tabular}




\section{Estimated Time Sequence for Source Remediation Implementation at the Former CCC/USDA Property in Agra, Kansas (Cont.)}

\begin{tabular}{|c|c|c|c|c|c|c|}
\hline Activity & Month \# & $\begin{array}{c}\text { Frequency, } \\
\text { Timeframe }\end{array}$ & \begin{tabular}{|c|} 
Description and Locations \\
\end{tabular} & Media / Analytes & Conducted By & Report to USDA / KDHE \\
\hline $\begin{array}{l}\text { Weekly Maintenance, As } \\
\text { needed }\end{array}$ & $\begin{array}{c}\text { As } \\
\text { needed }\end{array}$ & $\begin{array}{l}\text { As needed, if } \\
\text { system auto dialer } \\
\text { reports failure/fault } \\
\text { conditions. }\end{array}$ & $\begin{array}{l}\text { A site visit will be conducted to identify all problems and prevent future } \\
\text { malfunctions indicated by abnormal operating conditions. Preventative } \\
\text { maintenance shall include inspection of all gauges, filters, and system } \\
\text { operating parameters. }\end{array}$ & None & $\begin{array}{l}\text { Greenfield, } \\
\text { Argonne oversight }\end{array}$ & $\begin{array}{l}\text { Argonne to be } \\
\text { immediately notified; } \\
\text { data to be included in } \\
\text { Quarterly Monitoring } \\
\text { Report }\end{array}$ \\
\hline $\begin{array}{l}\text { First } 6 \text { Months } \\
\text { Maintenance and } \\
\text { Monitoring }\end{array}$ & $\begin{array}{l}1,2,3,4 \\
5,6\end{array}$ & $\begin{array}{l}\text { Monthly, } 1 \text { st } 6 \\
\text { months of } \\
\text { operation }\end{array}$ & $\begin{array}{l}\text { Operate all } 5 \text { SVE wells simultaneously. Evaluate monitoring results to } \\
\text { modify system for optimal performance of SVE wells. Results from design } \\
\text { test may change operation sequence. }\end{array}$ & $\begin{array}{l}\text { Field screen air } \\
\text { effluent using a PID } \\
\text { for VOCs. }\end{array}$ & $\begin{array}{l}\text { Greenfield, } \\
\text { Argonne oversight }\end{array}$ & $\begin{array}{l}\text { Quarterly Monitoring } \\
\text { Report }\end{array}$ \\
\hline Monthly OMM & $1-24$ & $\begin{array}{l}\text { Every month, } 2 \\
\text { years }\end{array}$ & $\begin{array}{l}\text { Correct system faults and failures reported by the autodialer through an } \\
\text { immediate site visit. Monthly, inspect (and repair, if needed) equipment, } \\
\text { gauges, filters, operating parameters, etc. Use a PID or equivalent to field- } \\
\text { screen air samples from SVE wells and effluent line for carbon } \\
\text { tetrachloride; field-screen effluent and extracted vapors for oxygen. Check } \\
\text { all gauges and hour meters and record readings. Measure and record } \\
\text { wellhead vacuum and pressure readings for each SVE and AS well. Adjust } \\
\text { well flow rates as needed. Record SWL readings from wells. Conduct } \\
\text { manufacturer-recommended maintenance. }\end{array}$ & $\begin{array}{l}\text { Field-screen air } \\
\text { effluent for VOCs by } \\
\text { using a PID or } \\
\text { equivalent. }\end{array}$ & $\begin{array}{l}\text { Greenfield, } \\
\text { Argonne oversight }\end{array}$ & $\begin{array}{l}\text { Quarterly Monitoring } \\
\text { Report }\end{array}$ \\
\hline Quarterly OMM & $\begin{array}{l}3,6,9,12 \\
15,18,21 \\
24\end{array}$ & $\begin{array}{l}\text { Quarterly, two } \\
\text { years }\end{array}$ & $\begin{array}{l}\text { Perform all standard monthly OMM. Measure and record vacuum, pressure, } \\
\text { and flow rates at SVE and AS wells. Measure vacuum readings at MW-P } \\
\text { and proposed wells GW-1, GW-2, GW-3, GW-4, and GW-5. Gauge, purge, } \\
\text { and sample monitoring wells MW-J and MW-P and proposed wells GW-1 } \\
\text { through GW-5. Measure and record DO levels at all wells. Collect air } \\
\text { effluent samples from each SVE well for laboratory analysis. }\end{array}$ & $\begin{array}{l}\text { Field screen air } \\
\text { effluent for VOCs by } \\
\text { using a PID or } \\
\text { equivalent, plus } \\
\text { laboratory analysis. }\end{array}$ & $\begin{array}{l}\text { Greenfield, } \\
\text { Argonne oversight }\end{array}$ & $\begin{array}{l}\text { Quarterly Monitoring } \\
\text { Report }\end{array}$ \\
\hline Soil Verification Sampling & TBD & Once, 1 week & $\begin{array}{l}\text { Collect vertical profile soil samples adjacent to LDBs to determine if cleanup } \\
\text { standards have been met. This sampling will be conducted at the end of } 2 \\
\text { yrs or if asymptotic concentrations are observed during operation of the } \\
\text { remedial system. }\end{array}$ & VOCs analyses & Argonne & $\begin{array}{l}\text { Verification soil sampling } \\
\text { summary report. }\end{array}$ \\
\hline System Evaluation & TBD & TBD & $\begin{array}{l}\text { Install a soil vapor monitoring network prior to system start-up to monitor the } \\
\text { long-term impact to soils. After } 2 \text { yrs of operation or when effluent data } \\
\text { indicate that asymptotic levels have been achieved, conduct vertical } \\
\text { profiling of the soil in the immediate vicinity of the LDBs. Submit a work plan } \\
\text { for this scope of work to the KDHE for review. }\end{array}$ & $\begin{array}{l}\text { Soil sampling for } \\
\text { VOCs analyses }\end{array}$ & Argonne & $\begin{array}{l}\text { Included in separate } \\
\text { report. }\end{array}$ \\
\hline System Termination & TBD & TBD & $\begin{array}{l}\text { Continue system operation until system shutdown is approved by the } \\
\text { KDHE. }\end{array}$ & None & Argonne & $\begin{array}{l}\text { Included in separate } \\
\text { report. }\end{array}$ \\
\hline
\end{tabular}

modified 230 ct08 
Drawings 


\section{List of Drawings}

- Drawing 5.1.0 Cover Sheet

- Drawing Argonne-1 Proposed Locations for Remediation Trailer and Trench Lines

- Drawing 5.1.2A Process and Instrumentation Diagram Legend

- Drawing 5.1.2B Soil Vapor Extraction Process and Instrumentation Diagram

- Drawing 5.1.2C Air Sparge Process and Instrumentation Diagram

- Drawing 5.1.3A Equipment Layout Details

- Drawing 5.1.3B Soil Vapor Extraction Manifold Details

- Drawing 5.1.3C $\quad$ Air Sparge Manifold Details

- Drawing 5.1.3D Miscellaneous Details

- Drawing 5.1.4 SVE and Air Sparge Well Details

- Drawing 5.2.1A Electrical Legend

- Drawing 5.2.1B Remediation System Electrical Schematic

- Drawing 5.2.1C Auto-Dialer Alarm Logic

- Drawing 5.2.1D Electrical One-Line Wiring Diagram 


\section{REMEDIAL DESIGN PLAN DRAWINGS \\ FOR \\ FORMER CCC / USDA FACILTY \\ AGRA, KANSAS}

KDHE SITE ID NO: C6-074-00002

\begin{tabular}{|c|l|l|l|}
\hline DWG. NO. & \multicolumn{1}{|c|}{ DRAWING NAME } & REVISION: & REVISION DATE: \\
\hline 5.1 .1 & REMEDIATION SITE PLAN & & \\
\hline $5.1 .2 \mathrm{~A}$ & P \& I D LEGEND & & \\
\hline $5.1 .2 \mathrm{~B}$ & SOIL VAPOR EXTRACTION P \& ID & & \\
\hline $5.1 .2 \mathrm{C}$ & AIR SPARGE P \& ID & & \\
\hline $5.1 .3 \mathrm{~A}$ & EQUIPMENT LAYOUT DETAILS & & \\
\hline 5.1 .38 & SVE MANIFOLD DETAILS & & \\
\hline $5.1 .3 \mathrm{C}$ & AIR SPARGE MANIFOLD DETAILS & & \\
\hline 5.1 .30 & MISCELLANEOUS DETAILS & & \\
\hline 5.1 .4 & SVE \& AIR SPARGE WELL DETAILS & & \\
\hline $5.2 .1 \mathrm{~A}$ & ELECTRICAL LEGEND & & \\
\hline $5.2 .1 \mathrm{~B}$ & ELECTRICAL SCHEMATIC & & \\
\hline $5.2 .1 \mathrm{C}$ & AUTO DIALER/ ALARM LOGIC & & \\
\hline 5.2 .10 & ELECTRICAL ONE-LINE WIRING DIAGRAM & & \\
\hline
\end{tabular}

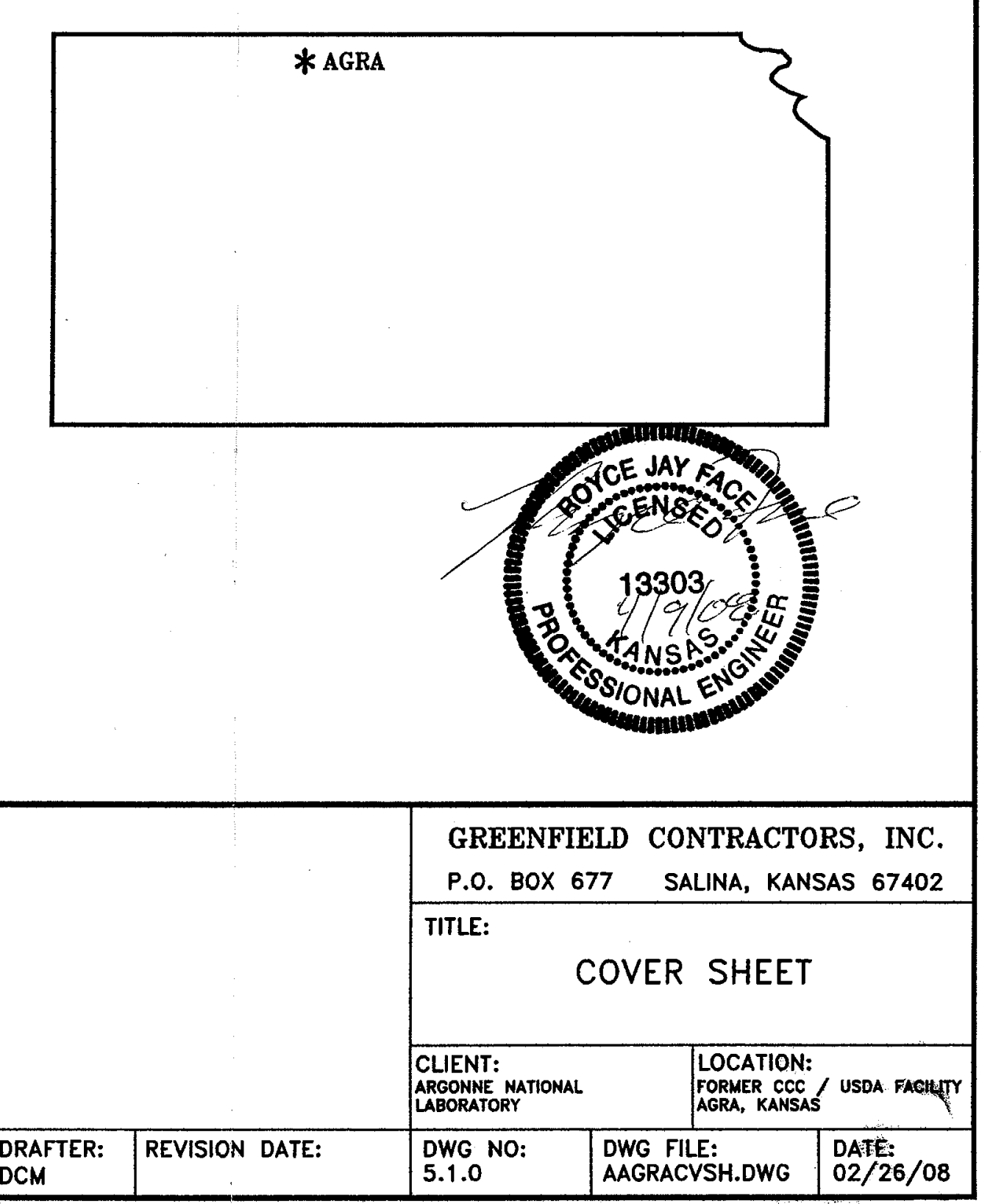




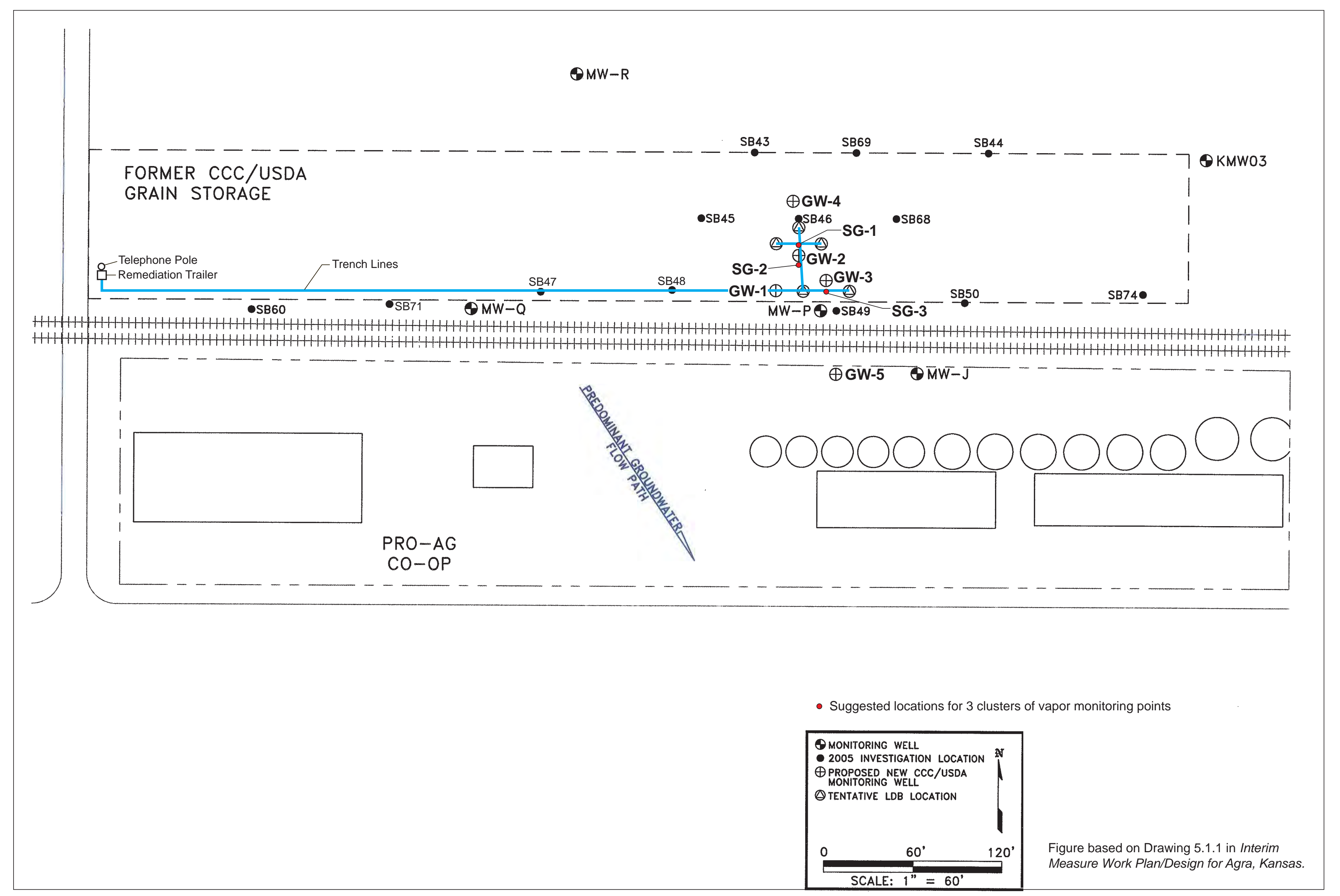

Proposed locations for remediation trailer and trench lines (locations may change after pilot test data is obtained). Drawing Argonne-1 


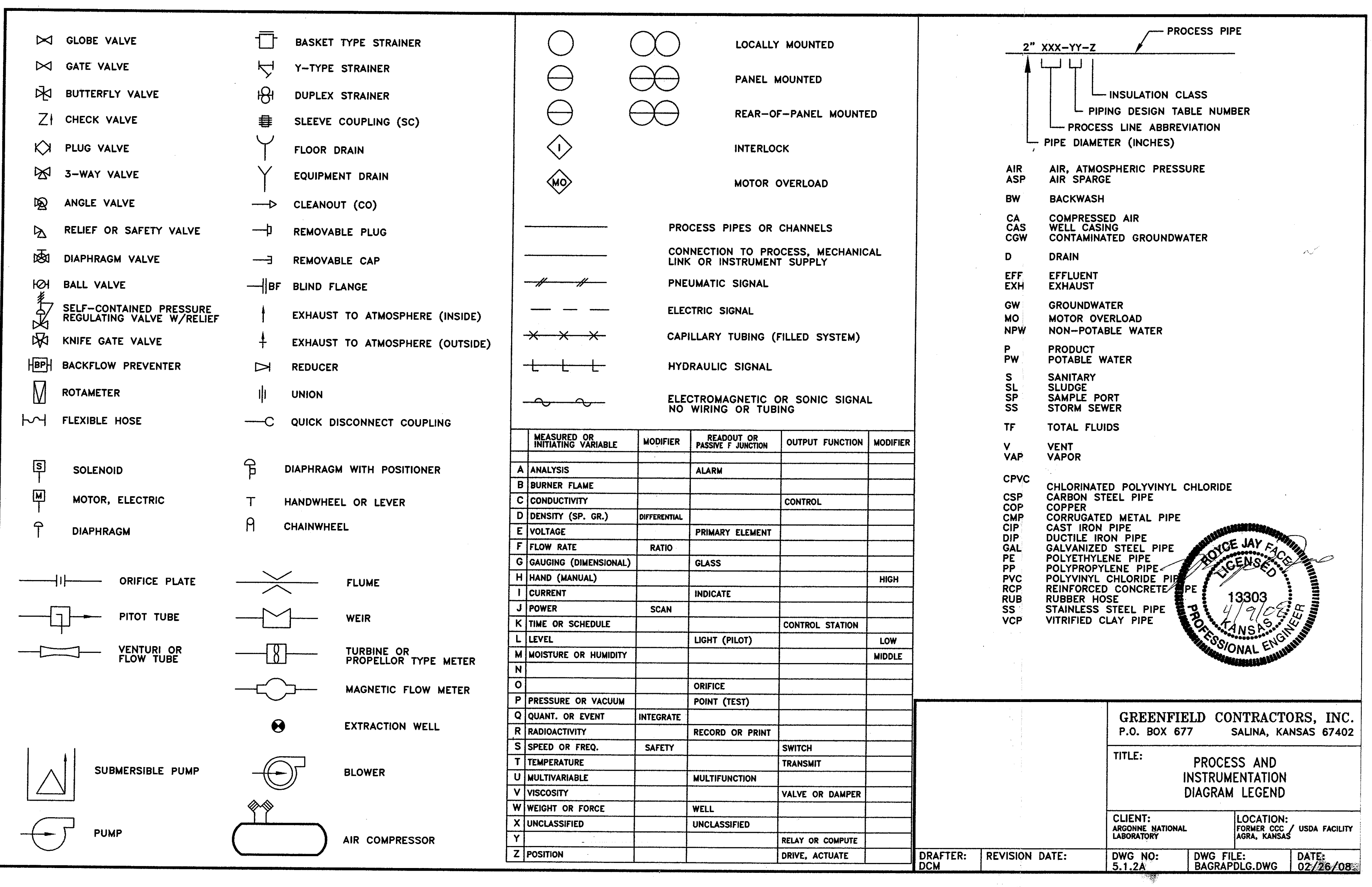




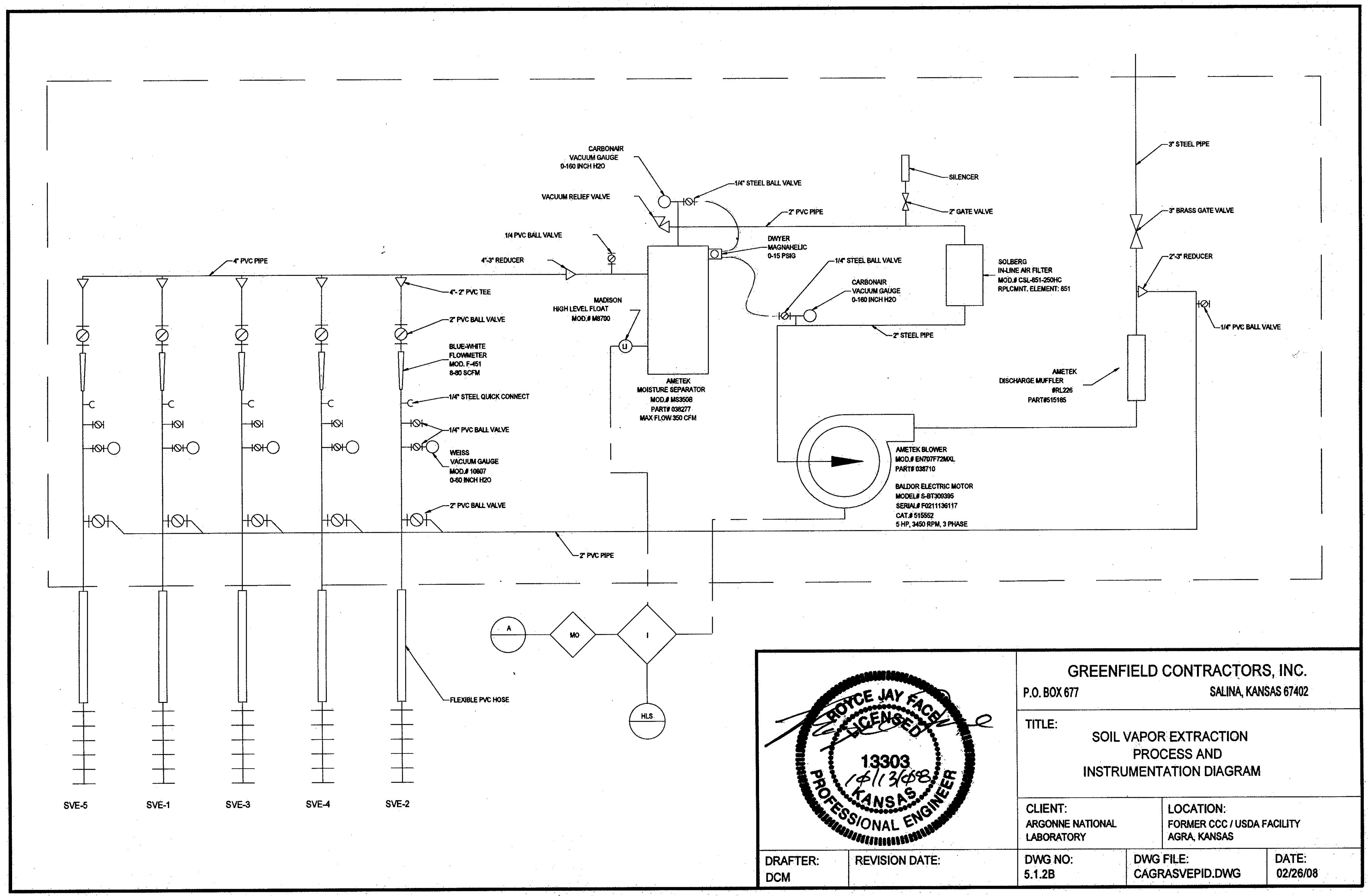




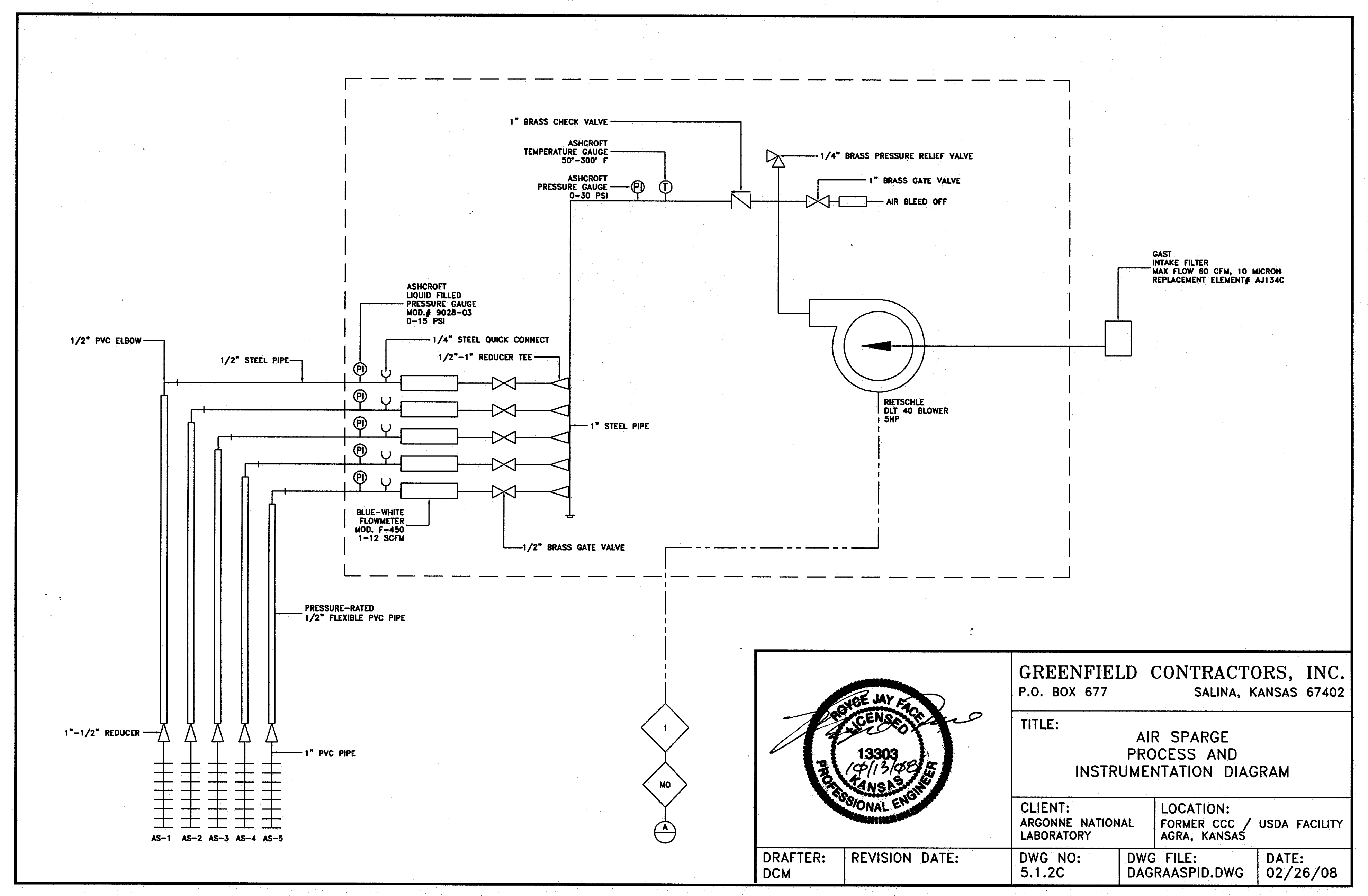




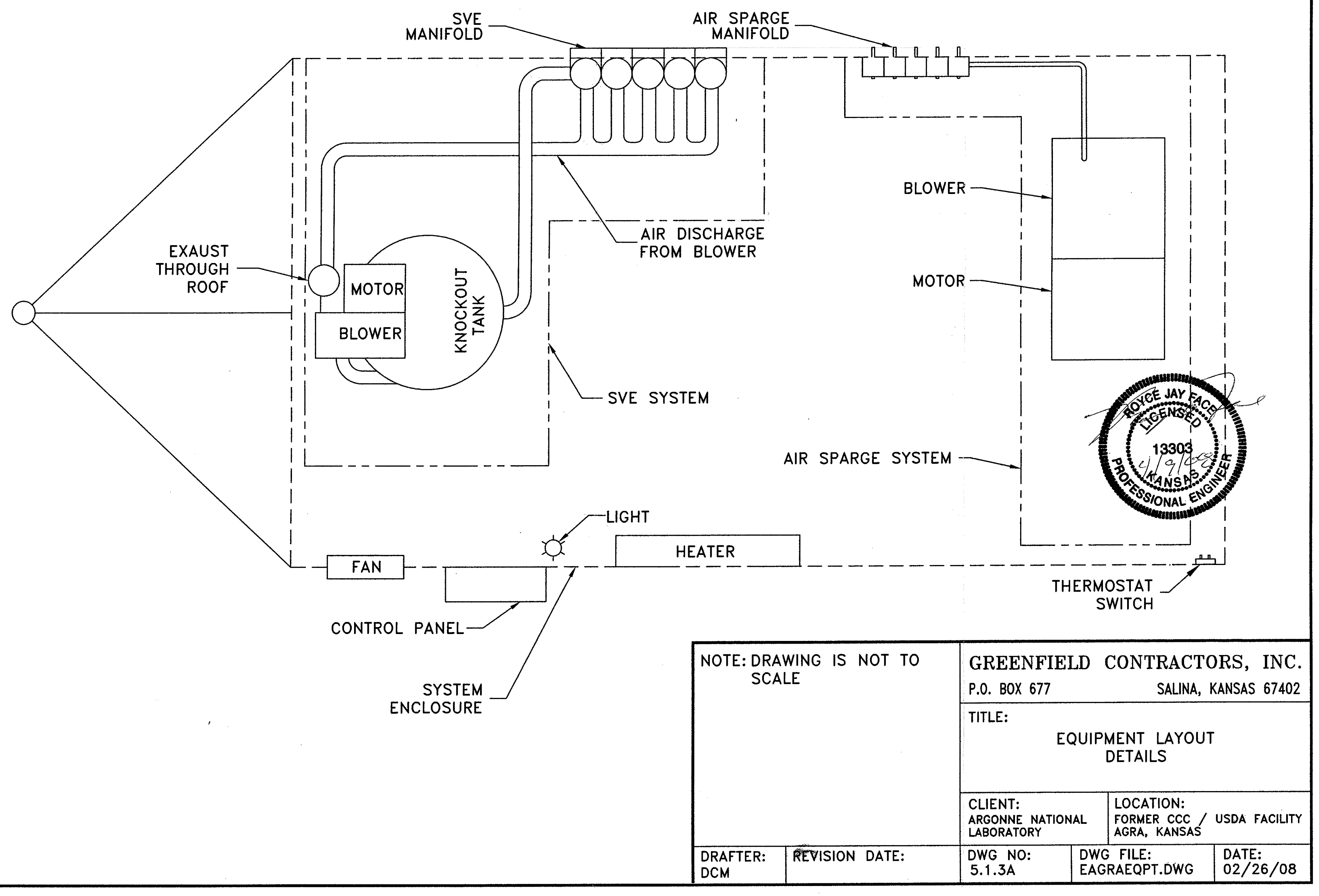




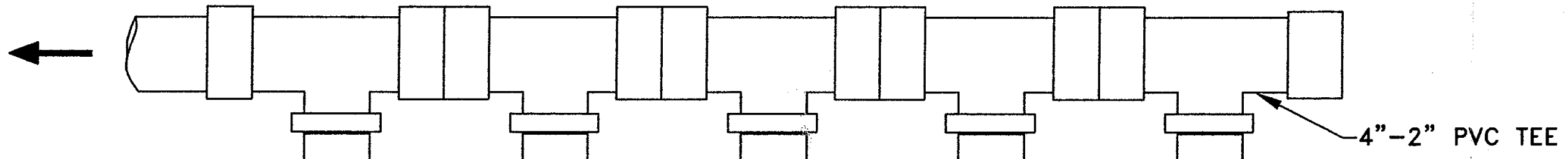

AIR DISCHARGE FROM BLOWER
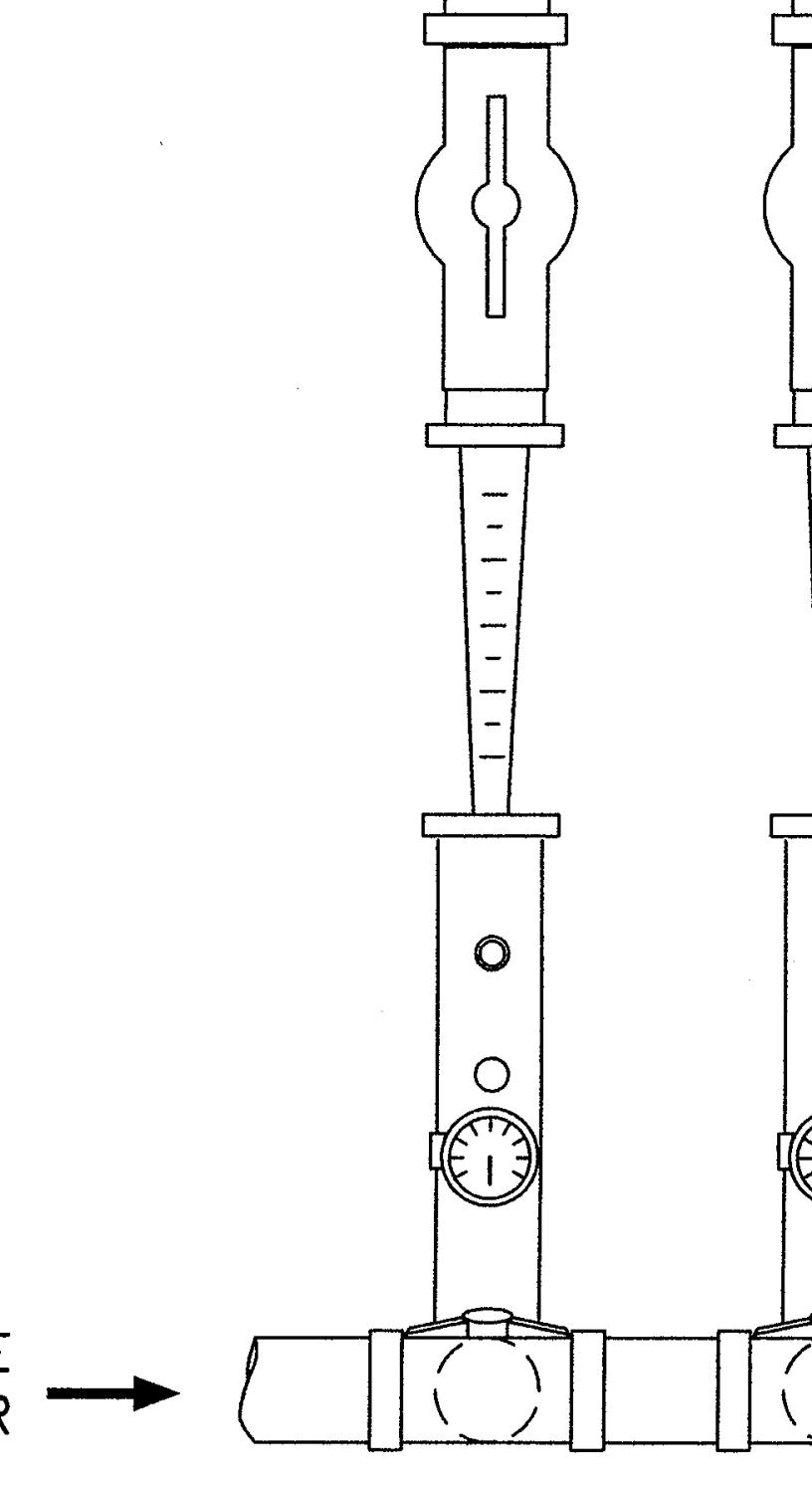

SVE-5

SVE-1

SVE

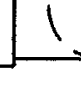

SVE MANIFOLD

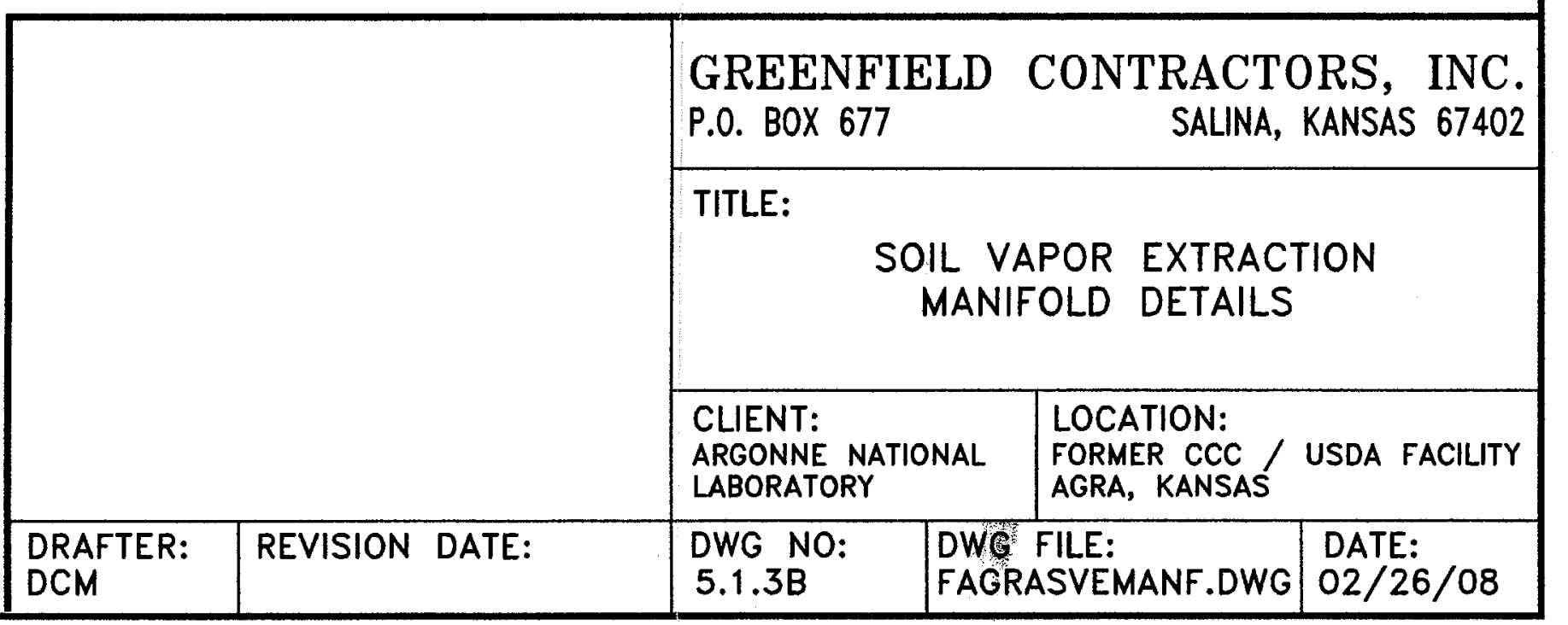




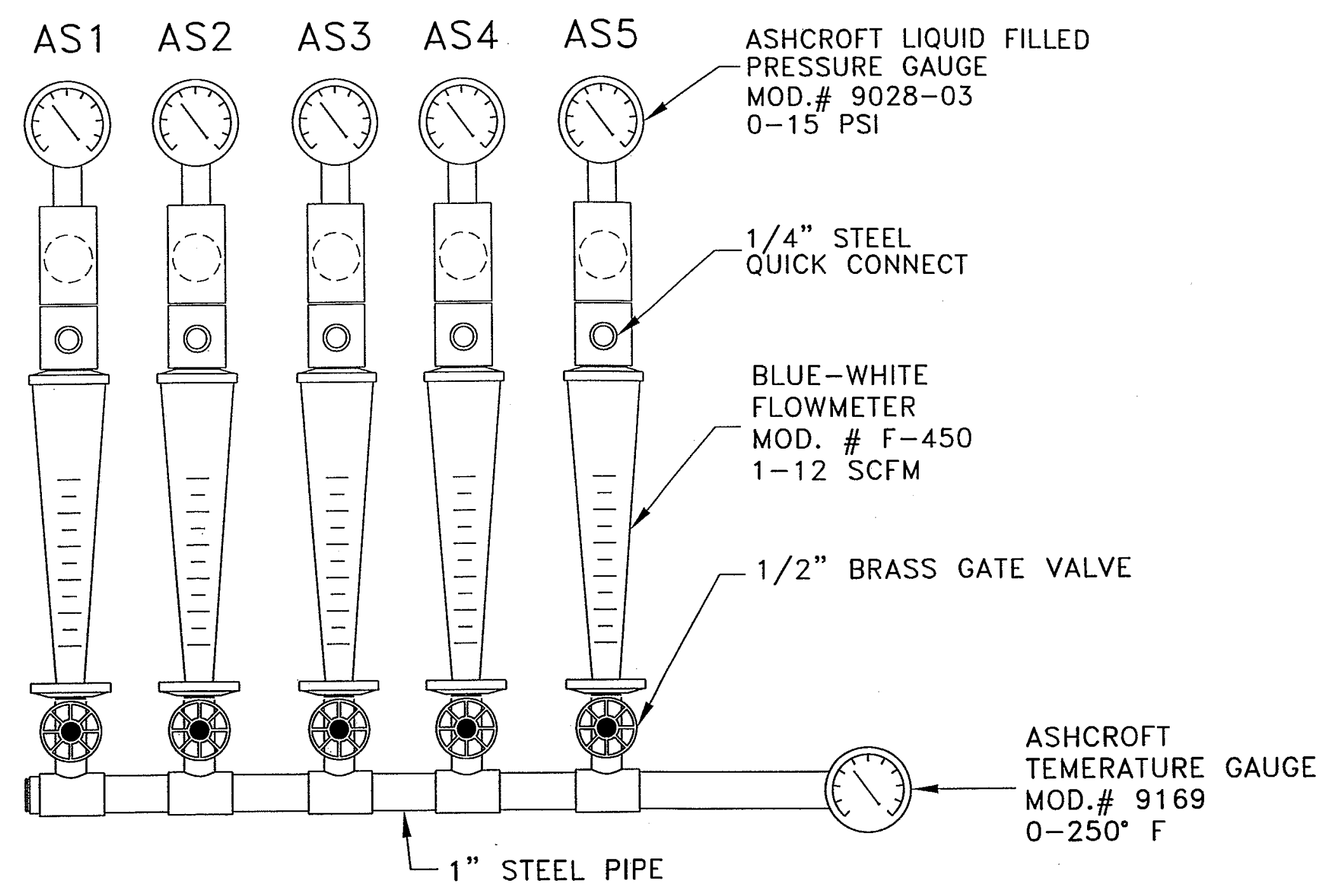

AIR SPARGE MANIFOLD

\begin{tabular}{|c|c|c|c|c|}
\hline & & $\begin{array}{l}\text { GREENFIELI } \\
\text { P.0. BOX } 677\end{array}$ & $\begin{array}{l}\text { CONTRACTC } \\
\text { SALINA, }\end{array}$ & $\begin{array}{l}\text { RS, INC. } \\
\text { KANSAS } 67402\end{array}$ \\
\hline & & TITLE: & $\begin{array}{l}\text { AIR SPARGE } \\
\text { NIFOLD DETAILS }\end{array}$ & \\
\hline & & $\begin{array}{l}\text { CLIENT: } \\
\text { ARGONNE NATIONA } \\
\text { LABORATORY } \\
\end{array}$ & \begin{tabular}{l|l} 
& LOCATION: \\
FORMER CCC \\
AGRA, KANSAS
\end{tabular} & USDA FACILITY \\
\hline $\begin{array}{l}\text { DRAFTER } \\
\text { DCM }\end{array}$ & REVISION DATE: & \begin{tabular}{l|l} 
DWG NO: & l \\
$5.1 .3 \mathrm{C}$ &
\end{tabular} & $\begin{array}{l}\text { DWG FILE: } \\
\text { GAGRAASMANF.DWG }\end{array}$ & \begin{tabular}{|l} 
DATE: \\
02/26/08
\end{tabular} \\
\hline
\end{tabular}




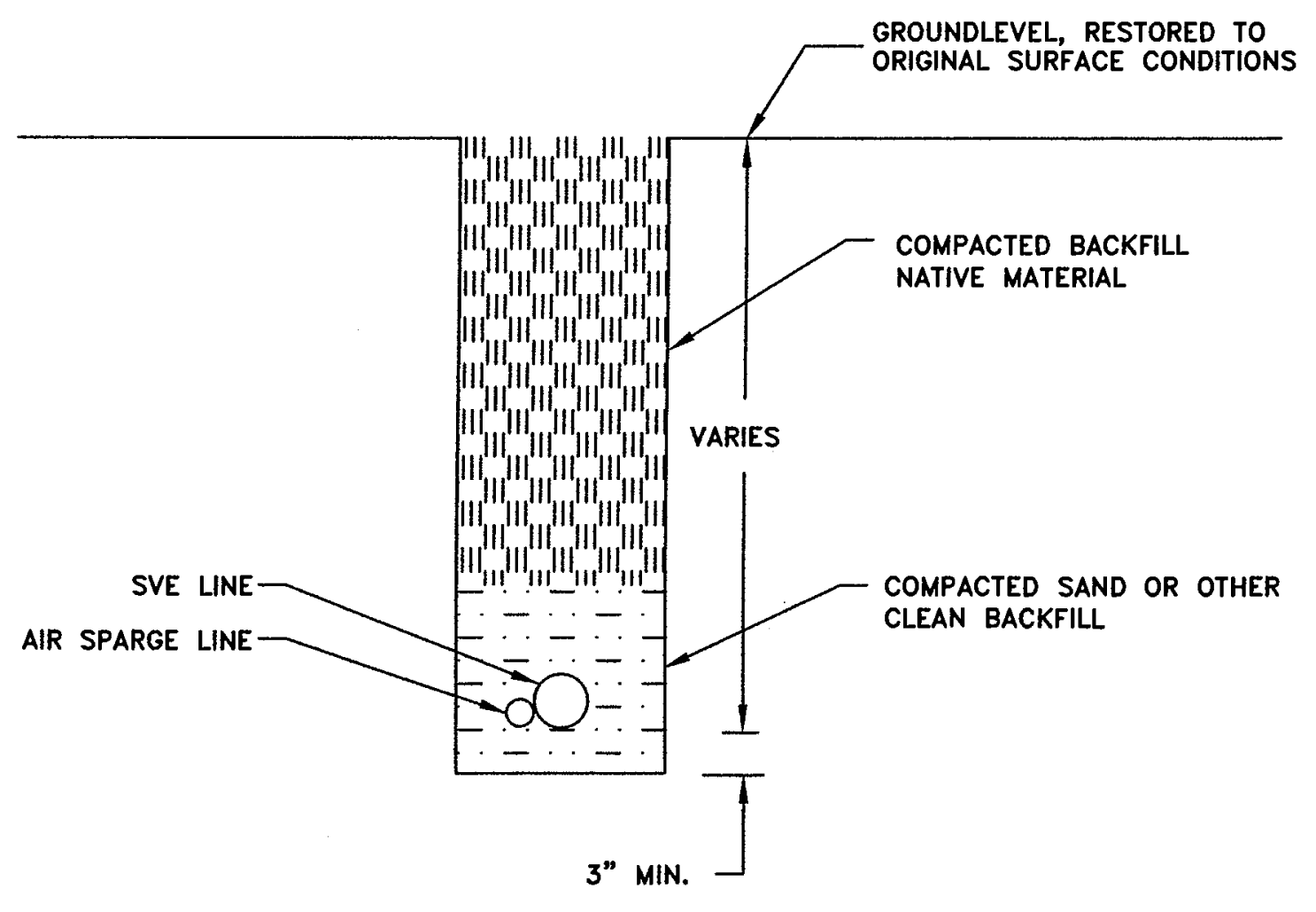

PIPE TRENCH DETAIL

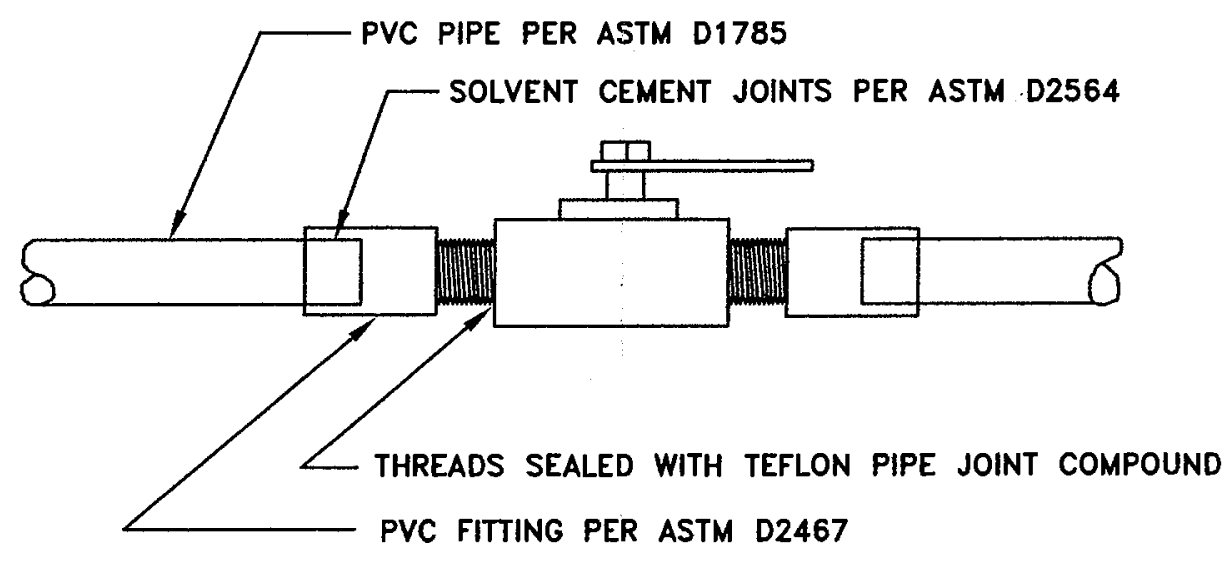

TYPICAL FITTING DETAIL

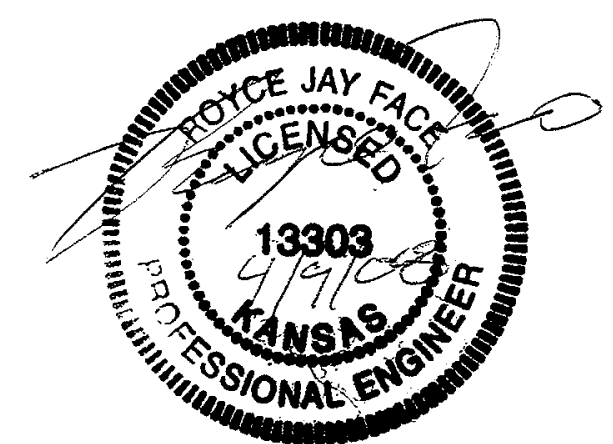

NOTE: NOT TO SCALE

\begin{tabular}{|c|c|c|c|c|c|}
\hline & & \multicolumn{4}{|c|}{$\begin{array}{l}\text { GREENFIELD CONTRACTORS, INC. } \\
\text { P.0. BOX } 677\end{array}$} \\
\hline & & \multicolumn{4}{|c|}{ MISCELLANEOUS DETAILS } \\
\hline & & \multicolumn{2}{|c|}{$\begin{array}{l}\text { CLIENT: } \\
\text { ARGONNE NATIONAL } \\
\text { LABORATORY }\end{array}$} & \multicolumn{2}{|c|}{$\begin{array}{l}\text { LOCATION: } \\
\text { FORER CCC / USDA FACILITY } \\
\text { AGRA, KANSAS }\end{array}$} \\
\hline $\begin{array}{l}\text { DRAFTER: } \\
\text { DCM }\end{array}$ & REVISION DATE: & $\begin{array}{l}\text { DWG NO: } \\
5.1 .3 \mathrm{D}\end{array}$ & & $\begin{array}{l}\text { G FILE: } \\
\text { GRAMISC.DWG }\end{array}$ & $\begin{array}{l}\text { DATE: } \\
02 / 26 / 08\end{array}$ \\
\hline
\end{tabular}




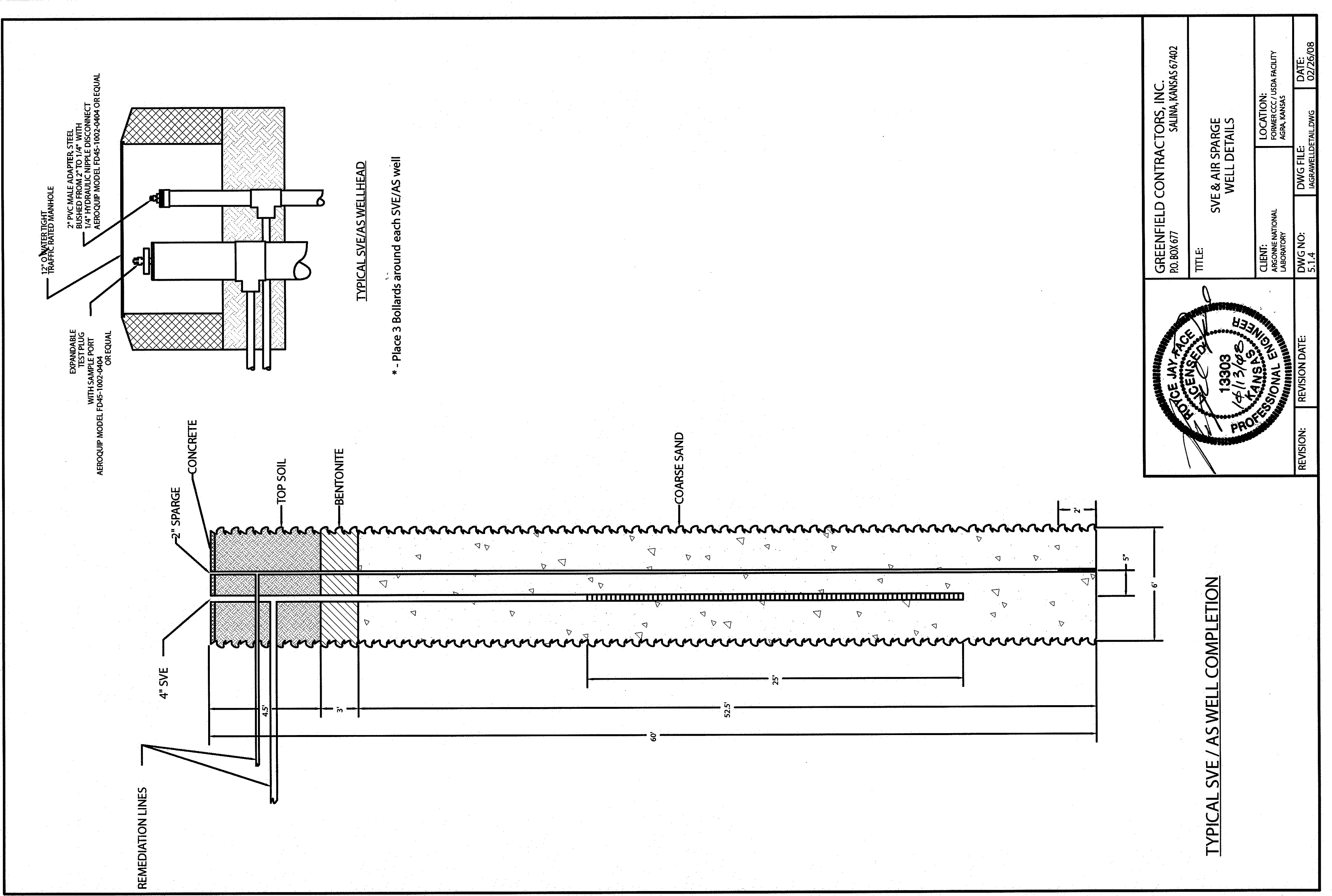




$\begin{array}{ll}\text { AUTO } & \text { AUTOMATIC } \\ \text { AFF } & \text { ABOVE FIIISH FLOOR } \\ \text { AFG } & \text { ABOVE FINISH GROUND } \\ \text { BC } & \text { BARE COPPER } \\ \text { CB } & \text { CONDUIT } \\ \text { CLIRCUIT BREAKER } \\ \text { CL } & \text { CLOSE } \\ \text { CPT } & \text { CONTROL POWER TRANSFORMER } \\ \text { CR } & \text { CONTROL RELAY } \\ \text { CS } & \text { CONTROL SWICH } \\ \text { CT } & \text { CURRENT TRANSFORMER } \\ \text { DWG } & \text { DRAWING TIME METER } \\ \text { ETM } & \text { ELASPED TIME } \\ \text { FU } & \text { FUSE } \\ \text { FWD } & \text { FORWARD } \\ \text { GND } & \text { GROUND } \\ & \text { HAND } \\ \text { HS } & \text { HIGH } \\ \text { HS } & \text { HIGH SPEED } \\ \text { IL } & \text { INDICATING LIGHT } \\ \text { LOW } & \text { LOCAL } \\ \text { ES } & \text { LOCAL SPEED } \\ \text { MAN } & \text { MOWUAL } \\ \text { MCC } & \text { MOTOR CONTROL CENTER } \\ \end{array}$

$\begin{array}{ll}\text { NC } & \text { NORMALLY CLOSED } \\ \text { NL } & \text { NIGHT LIGHT } \\ \text { NO } & \text { NORMALLY OPEN } \\ 0 & \text { OFF } \\ \text { OL } & \text { THERMAL OVERLOAD RELAY } \\ \text { OP } & \text { OPEN } \\ \text { PB } & \text { PUSHBUTTON } \\ \text { PLC } & \text { PROGRAMMABLE LOGIC } \\ & \text { CONTROLER } \\ \text { REM } & \text { REMOTE } \\ \text { REV } & \text { REVERSE } \\ \text { SOL } & \text { SOLENOID } \\ \text { SP } & \text { SPARE } \\ \text { SS } & \text { SELECTOR SWITCH } \\ \text { SV } & \text { SOLENOID VALVE } \\ \text { TSTAT } & \text { THERMOSTAT } \\ \text { TDAE } & \text { TME DELAY AFTER ENERGIZED } \\ \text { TDAD } & \text { TMME DELAY AFTER DE-ENERGIZED } \\ \text { TDR } & \text { TIME DELAY RELAY } \\ \text { TEMP } & \text { TEMMPERATURE. } \\ \text { TMR } & \text { TIMER } \\ \text { WP } & \text { WEATHER PROOF } \\ \text { XFMR } & \text { TRANSFORMER } \\ \text { XP } & \text { EXLOSIONPROOF-CLASS I, } \\ & \text { DIVISION I \& } \| \text {, GROUP C \& D }\end{array}$

\section{SCHEMATIC DIAGRAM SYMBOLS}
$\ominus \square$ TERMINAL
- CONDUCTOR CONNECTION
+ No CONNECTION
|l GROUND
- 1 - CONTACT NORMALLY OPEN
O
$->$ SWITCH
$\stackrel{\circ}{<O}$ S SELECTOR SWITCH

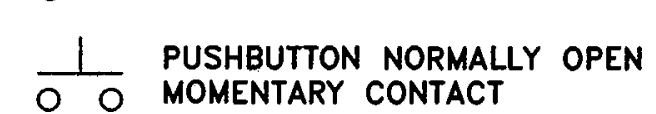 O 10 PUSHBUTTON NORMALLY CLOSED
O O PRESSURE OR VACUUM SWITCH
D CLOSES WITH INCREASING VACUUM
OTO PRESSURE OR VACUUM SWITCH
OTO CLSES WITH DECREASING
PRESSURE OR INCREASING
VACUUM

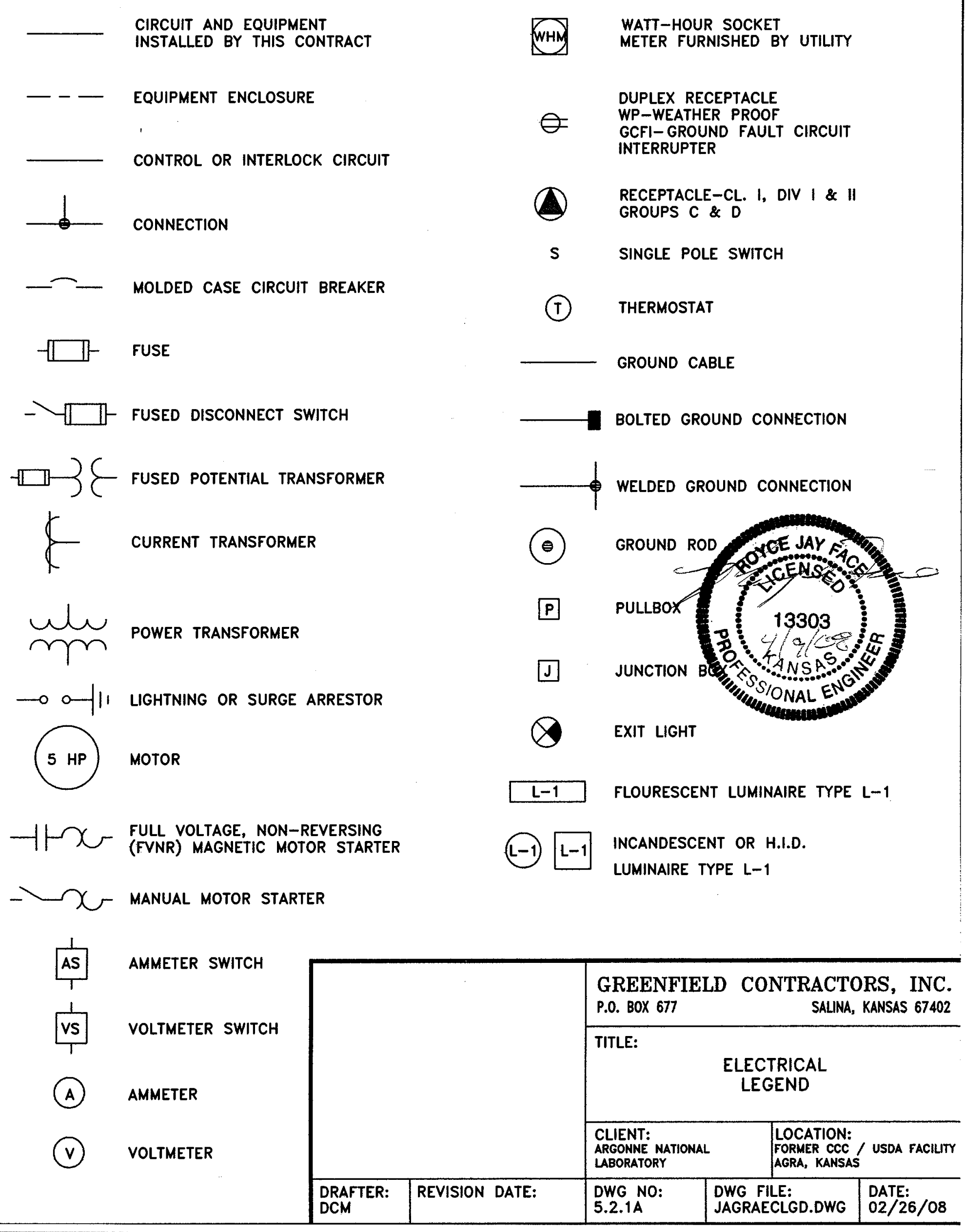




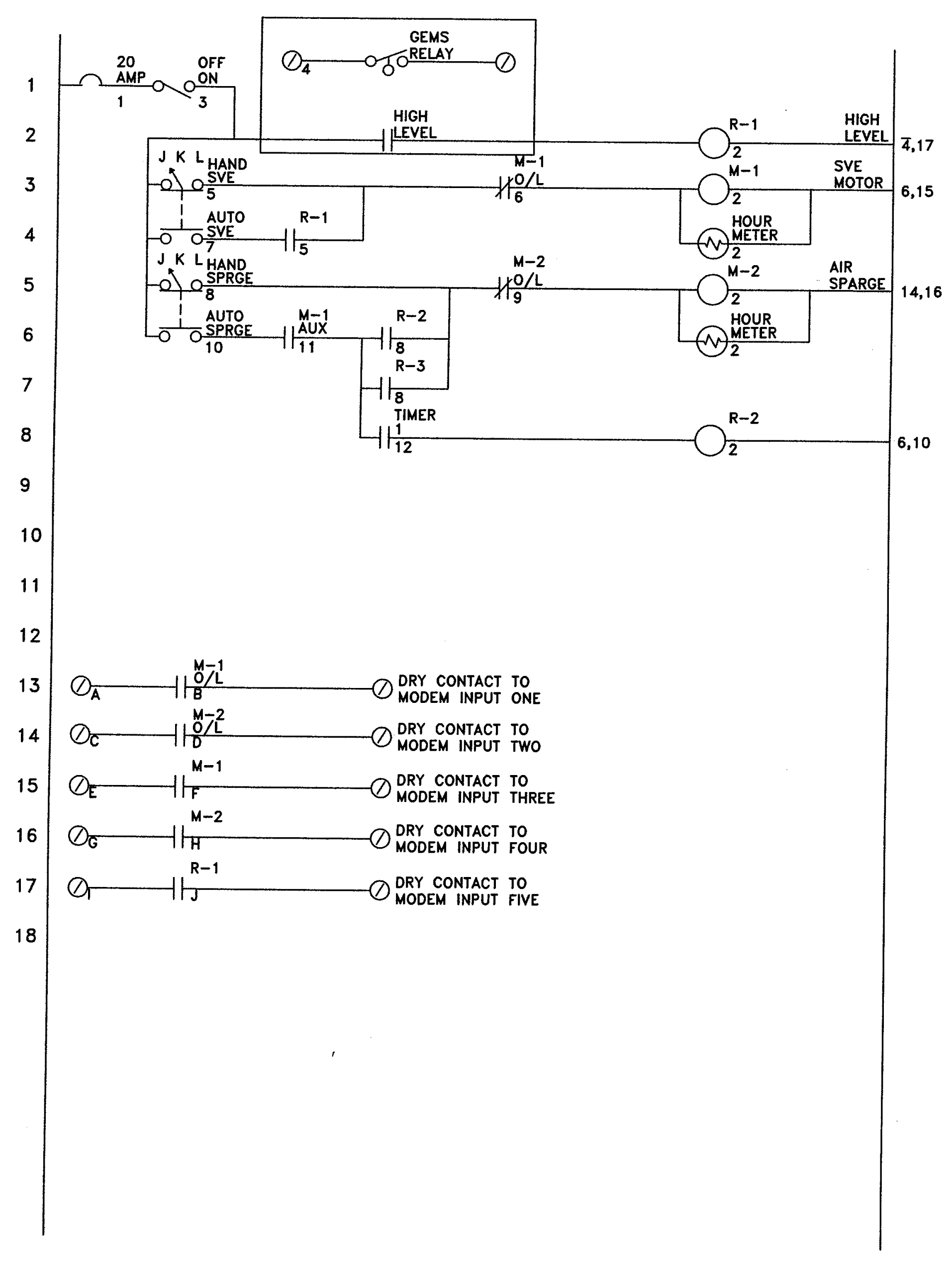

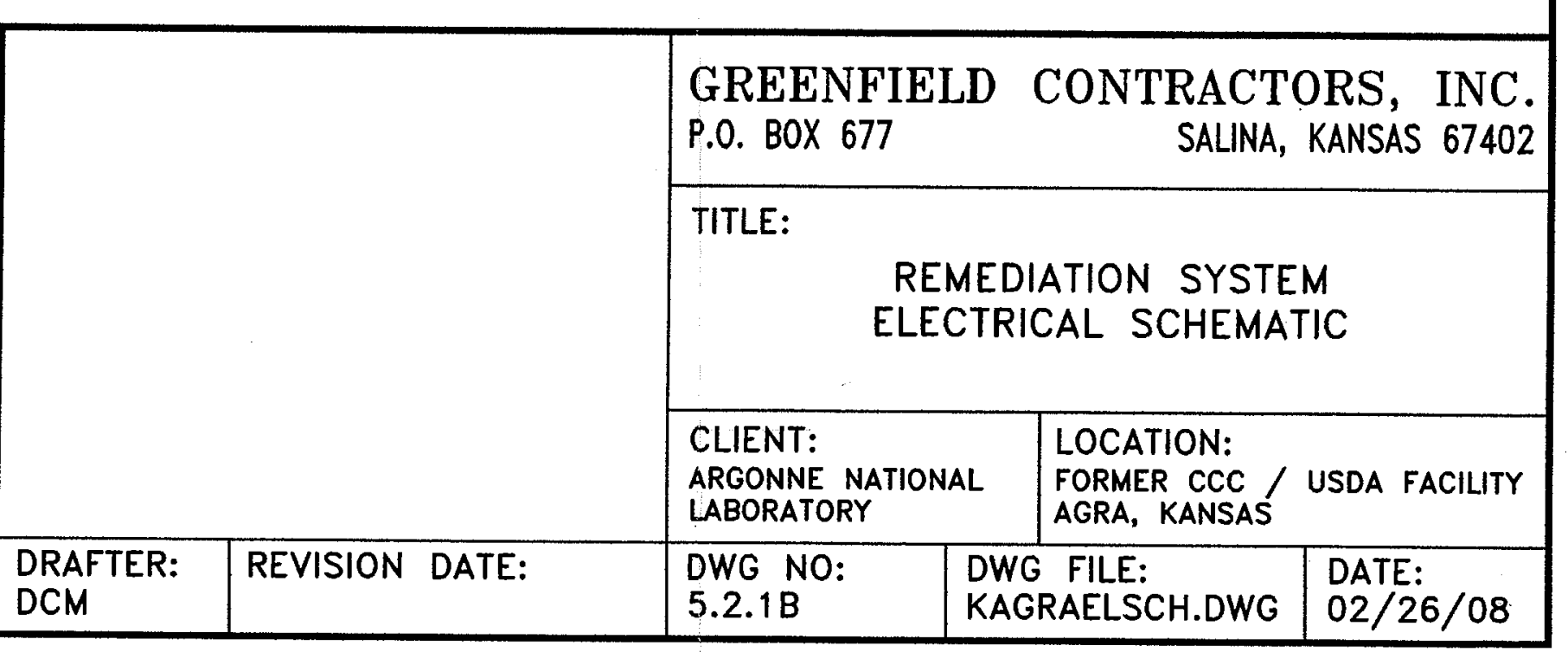




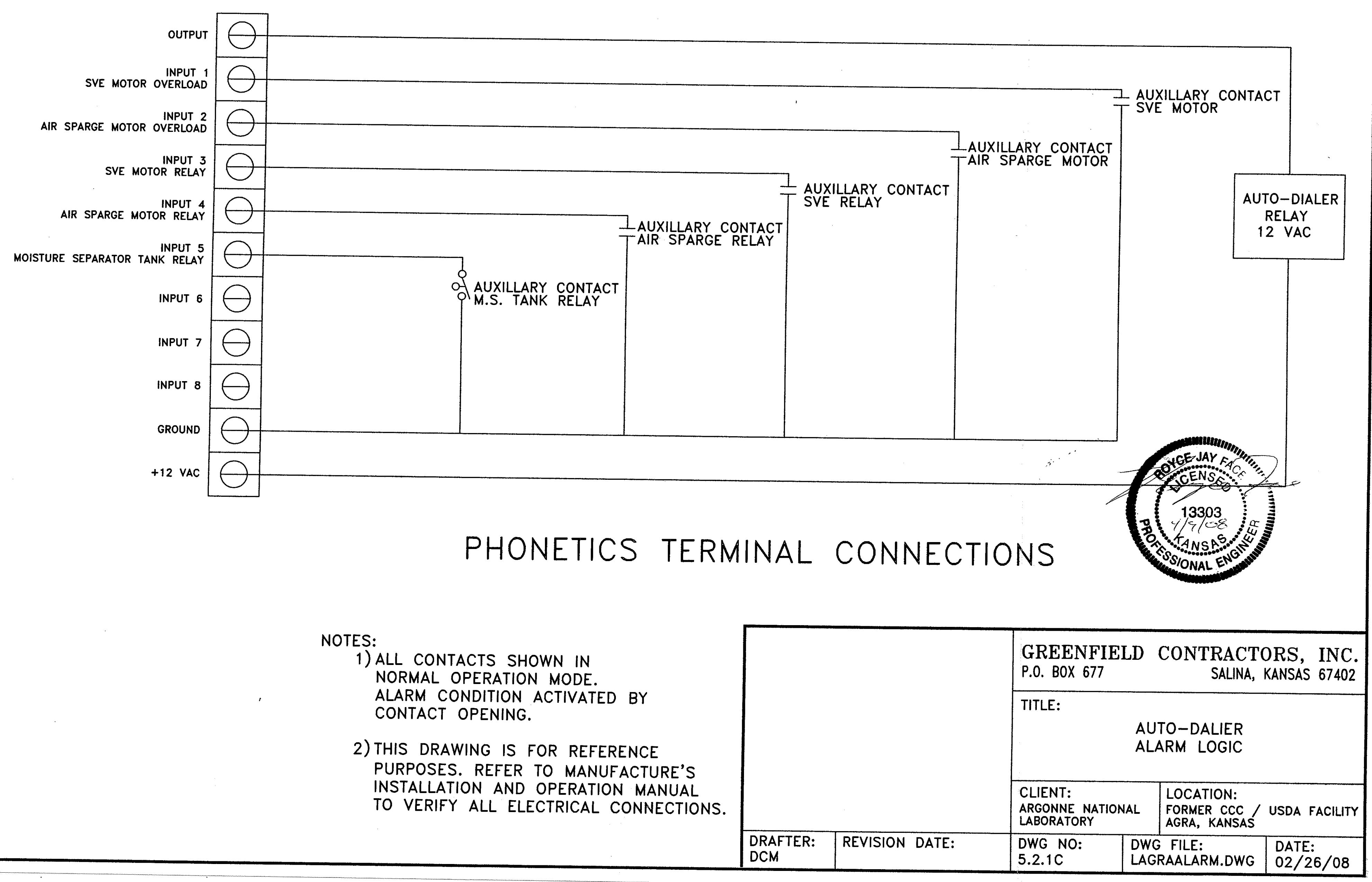




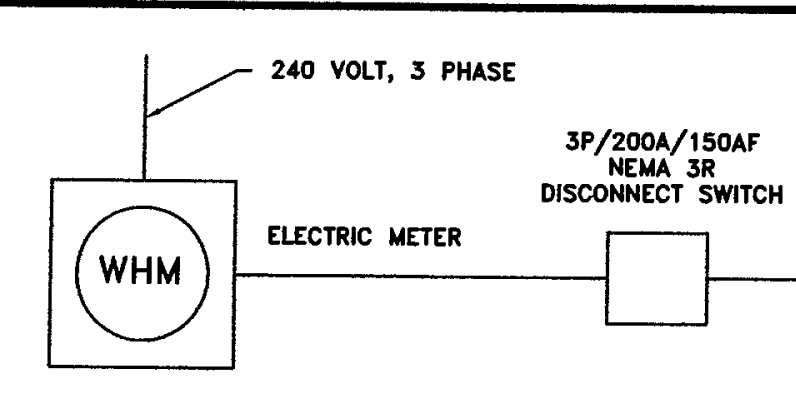

NOTE: REMEDAATION SYSTEM REQURES
ITS OWN METERED ELECTRICAL SERVICE
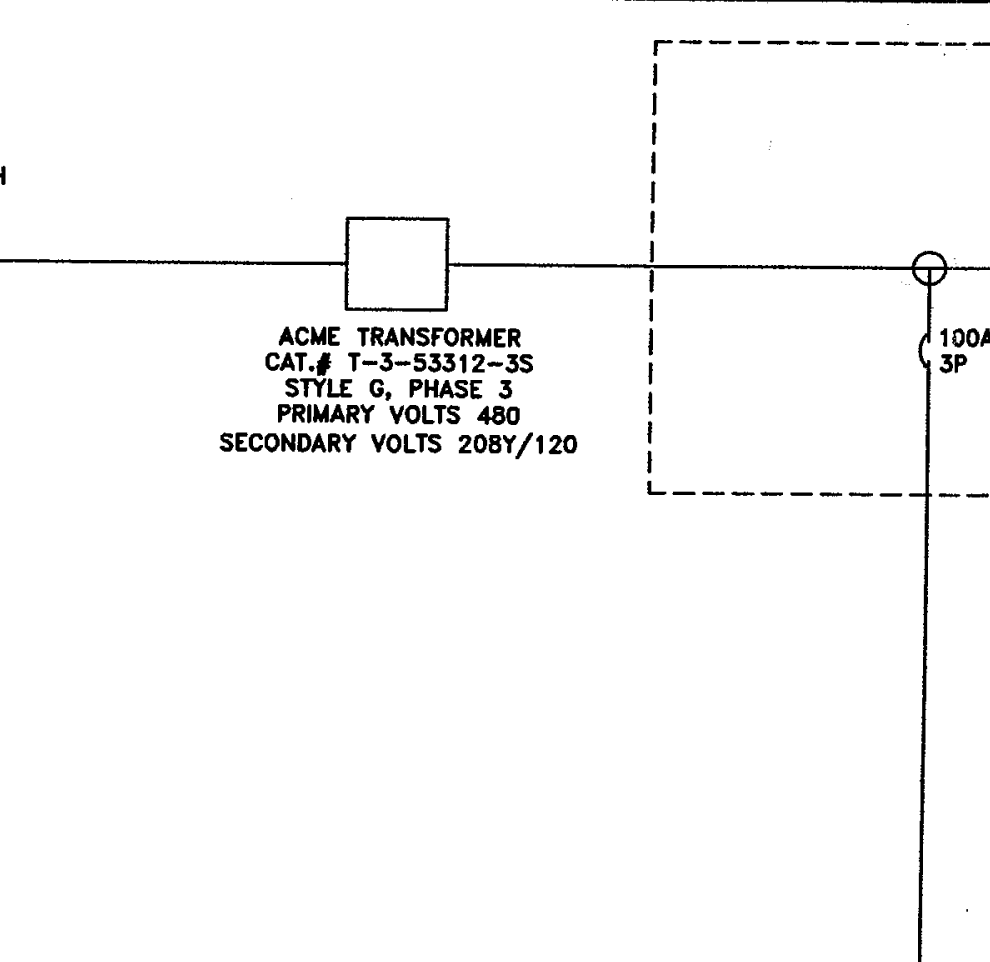

NEMA SR PANELBOARD

CONTROL PANEL

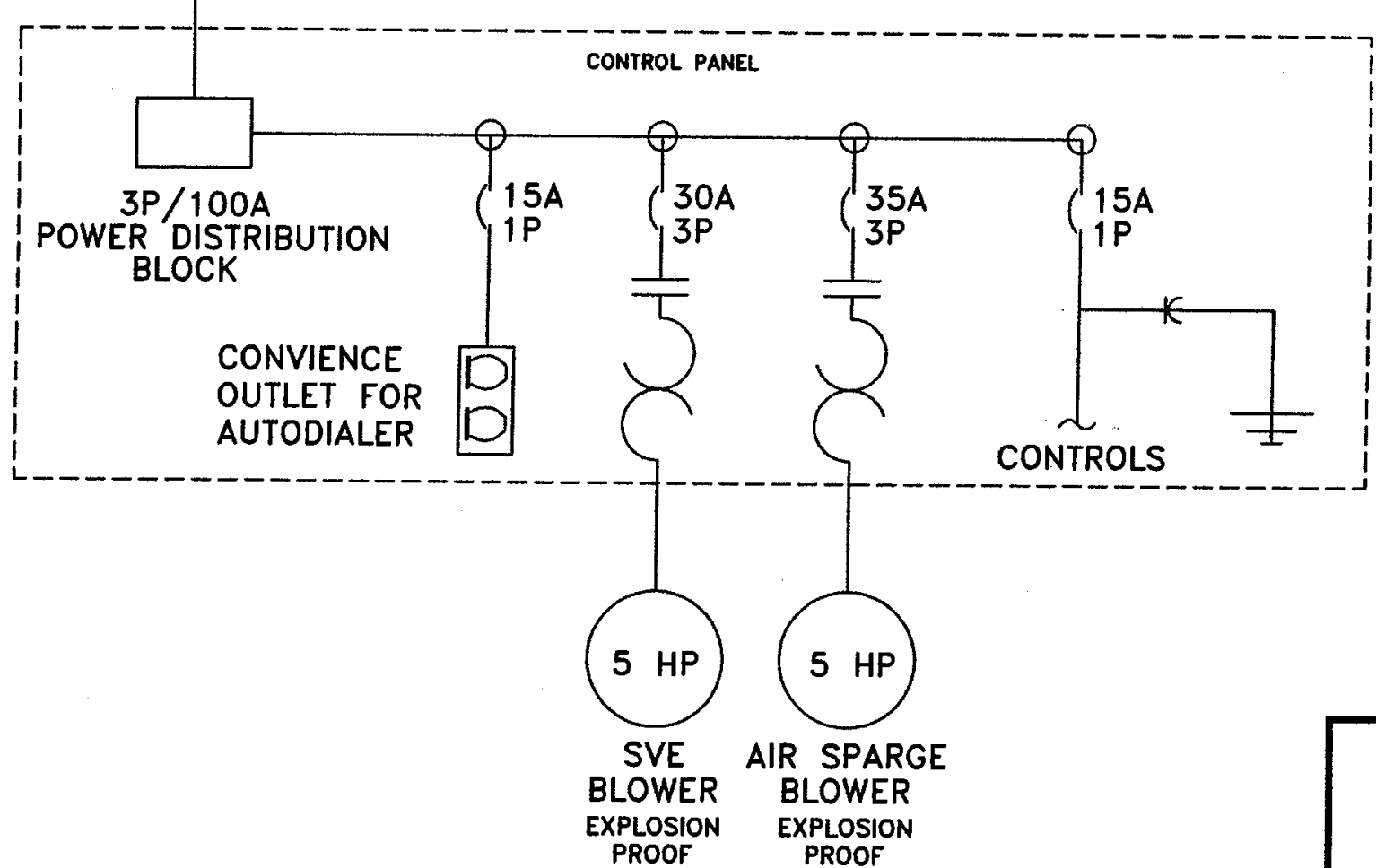

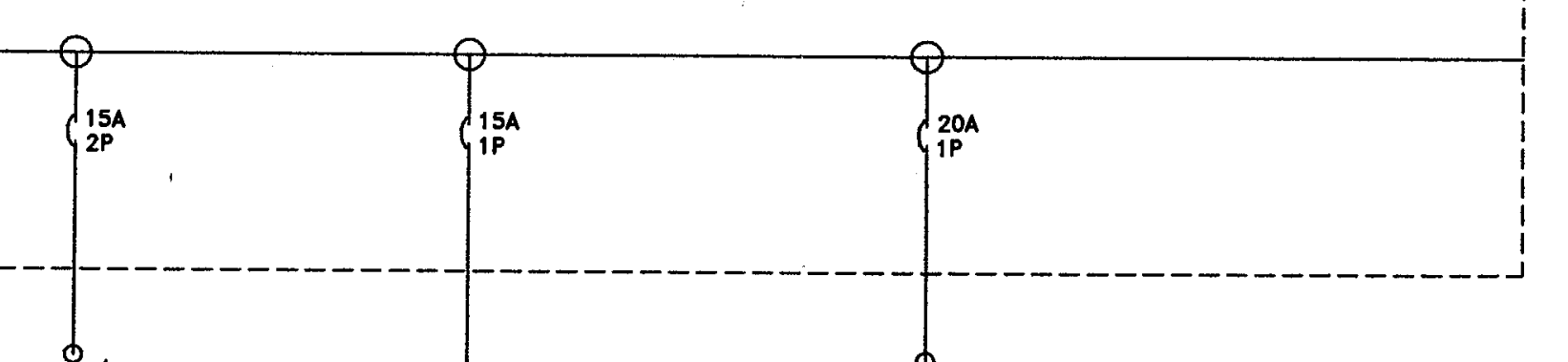

\begin{tabular}{|c|c|c|c|c|}
\hline & \multicolumn{3}{|c|}{$\begin{array}{l}\text { GREENFIELDD CONTRACTORS, INC. } \\
\text { P.O. BOX } 677 \\
\text { SALINA, KANSAS } 67402\end{array}$} \\
\hline & & \multicolumn{3}{|c|}{$\begin{array}{l}\text { TITLE: } \\
\text { ELECTRICAL ONE-LINE } \\
\text { WIRING DIAGRAM }\end{array}$} \\
\hline & & $\begin{array}{l}\text { CLLENT: } \\
\text { ARGONAE NATIONA } \\
\text { LABORATORY }\end{array}$ & $\begin{array}{l}\text { LOCATION: } \\
\text { FORMER CCC } \\
\text { AGA, KANSAS }\end{array}$ & USDA FACLLITY \\
\hline $\begin{array}{l}\text { DRAFTER: } \\
\text { DCM }\end{array}$ & REVISION DATE: & $\begin{array}{l}\text { DWG NO: } \\
5.2 .10\end{array}$ & $\begin{array}{l}\text { DWG FILE: } \\
\text { MAGRAELONE.DWC }\end{array}$ & $\begin{array}{l}\text { DATE: } \\
02 / 26 / 08\end{array}$ \\
\hline
\end{tabular}




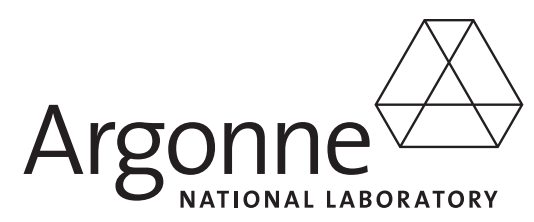

\section{Environmental Science Division}

Argonne National Laboratory

9700 South Cass Avenue, Bldg. 203

Argonne, IL 60439-4843

www.anl.gov

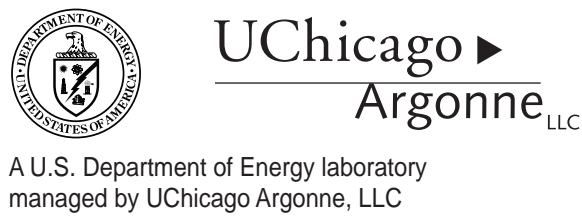

